\title{
Din Eğitimci ve Öğreticilerinin Mesleki Tutum ile Tükenmişlik Düzeyleri
}

\section{Süleyman Abanoz}

\author{
Dr., ÖSYM Uzmanı, Ölçme, Seçme ve Yerleştirme Merkezi \\ PhD., ÖSYM Specialist, Measuring, Selection and Placement Center \\ Ankara/Türkiye \\ abanoz_s@hotmail.com \\ ORCID: 0000-0002-4466-7080
}

\section{Levels of Professional Attitude and Burnout of Religious Educators and Teachers Abstract}

In recent years continues to increase interest in religion in Turkey and in the world. All that is effective in the world that the proliferation of groups claiming to live in the core of institutional religion, the rise of new religious movements and the politics of religious discourse in Turkey and the world is an example of this situation. In addition, in Turkey, interest in religious institutions and professions has increased significantly due to the demands of the people and the discourse and actions of political power. There are emotional, mental and behavioral dimensions of the religious officials' professional attitude, which is formed by his/her life related to his/her professionfeelings such as liking or disliking the profession form the emotional dimension of his/her professional attitude. His/her thoughts and knowledge about the profession constitute the cognitive (mental) dimension of professional attitude. The behavioral dimension of professional attitude is professional activities and work performed in accordance with their emotional and cognitive dimensions. Organization and work dimensions of burnout are important in terms of the formation and development of the burnout concept, since people spend most of their lives at work. They reflect their work life, organizational structure, even unintentionally, to their family and home lives. Workload weight, the nature of the job, work-friendliness relationships, communication, as well as the organization's management and organizational structure, the strategies and policies applied managerial practices and sanctions, laws, legistlations and regulations can lay the groundwork for the occurrence of burnout syndrome on an individual level. In this study, the level of professional attitude and burnout of employees in various titles in religious higher education institutions, Ministry of National Education and Presidency of Religious Affairs in seven metropolitan cities, each of

Bu çalışma 12.12.2019 tarihinde tamamladığımız Din Eğitimci ve Öğreticilerinin Mesleki Tutumları ile Tükenmişlik Düzeyleri Arasındaki İlişki başlıklı doktora tezi esas alınarak hazırlanmıştır. / This article is extracted from my doctorate dissertation entitled "Correlation Between Professional Attitude and Burnout of Religion Educators And Religion Teachers", (PhD [12.12.2019])

Intihal Taraması/Plagiarism Detection: Bu makale intihal taramasından geçirildi/This paper was checked for plagiarism Etik Beyan/Ethical Statement: Bu çalışmanın hazırlanma sürecinde bilimsel ve etik ilkelere uyulduğu ve yararlanılan tüm çalışmaların kaynakçada belirtildiği beyan olunur/It is declared that scientific and ethical principles have been followed while carrying out and writing this study and that all the sources used have been properly cited (Süleyman Abanoz).

Geliş/Received: 05 Mayıs/May 2021 | Kabul/Accepted: 08 Temmuz/July 2021 | Yayın/Published: 20 Eylül/September 2021

Atıf/Cite as: Süleyman Abanoz, "Din Eğitimci ve Öğreticilerinin Mesleki Tutum ile Tükenmişlik Düzeyleri = Levels of Professional Attitude and Burnout of Religious Educators and Teachers", Eskiyeni 45 (Eylül/September 2021), 719-751. https://doi.org/10.37697/eskiyeni.933270

CC BY-NC 4.0 | This paper is licensed under a Creative Commons Attribution-NonCommercial License 
which is located in different regions of Turkey, were examined. A questionnaire including demographic information, professional attitude and professional burnout scales was used as a data collection tool. Within the scope of the study, the questionnaires of a total of 3662 participants, including 282 academics, 1605 teachers and 1775 religious officials, were accepted as valid. The data obtained as a result of the study were analysed by SPSS 23.0 statistics program. In the study, the level of significance was determined as $p<0.05$. As a result of the analysis, a high-level inverse correlation was observed between professional burnout and professional attitude. Moreover, it has been determined that there is a significant relationship between variables such as marital status, age, length of service, gender, city of residence and education level, and professional attitude and burnout, although it varies from institution to institution. The place of residence, title, and the reason for choosing the profession have been observed to have a similar effect in all institutions in terms of professional attitude and burnout. The results obtained were interpreted by the researcher, and some suggestions were made based on the results.

\section{Keywords}

Psychology of Religion, Religious Education, Religious Teacher, Professional Attitude, Burnout

\section{Öz \\ Din Eğitimci ve Öğreticilerinin Mesleki Tutum ile Tükenmişlik Düzeyleri}

Son yıllarda dünyada ve Türkiye'de dine ilgi artarak devam etmektedir. Tüm dünyada etkili olan, kurumsal dinlerin özünü yaşama iddiasındaki grupların çoğalması, dinî söylemlerin Türkiye ve dünya siyasetinde artması ve ortaya çıkan yeni dinî hareketler bu duruma örnek oluşturmaktadır. Bunun yanında Türkiye'de, halkın bu yöndeki talepleri ve siyasi iktidarın söz ve eylemlerinin de etkisiyle dine, dinî kurum ve mesleklere ilgi oldukça artmıştır. Din görevlisinin mesleğiyle ilgili geçirdiği yaşantılarla oluşan mesleki tutumunun duygusal, zihinsel ve davranışsal boyutları bulunur. Mesleği sevme ya da sevmeme gibi duygular, mesleki tutumunun duygusal boyutunu oluşturur. Meslekle ilgili düşünce ve bilgileri mesleki tutumun bilişsel (zihinsel) boyutunu meydana getirmektedir. Mesleki tutumun davranış boyutu ise, duygusal ve bilişsel boyutlarına uygun olarak yapılan mesleki faaliyetler ve işlerdir. Tükenmişliğin örgüt ve iş boyutu, kavramın oluşumu ve gelişimi açısından önem taşımaktadır. Çünkü insanlar hayatlarının büyük bir kısmını işyerlerinde geçirmektedirler. İş yaşantılarını, örgüt yapılarını, istemeden de olsa aile ve ev yaşantılarına yansıtmaktadırlar. İş yükü ağırlığı, işin niteliğii, çalışma arkadaşlığı ilişkileri, iletişim ve bunun yanı sıra örgütün yönetim ve organizasyon yapısı, uygulanan strateji ve politikalar, yönetici uygulamaları ve yaptırımları, kanunlar, yasalar, yönetmelikler bireysel boyutta tükenmişlik sendromunun oluşuma zemin hazırlayabilmektedir. Bu çalışmada her biri Türkiye'nin farklı bölgelerinde yer alan yedi büyükşehirdeki dinî yükseköğretim kurumlarında, Millî Eğitim Bakanlığında ve Diyanet İşleri Başkanlığında çeşitli unvanlarda çalışanların mesleki tutum ve tükenmişlik düzeyleri incelenmiştir. Veri toplama aracı olarak demografik bilgiler, mesleki tutum ve mesleki tükenmişlik ölçeklerini içeren anket uygulanmıştır. Çalışma kapsamında 282 akademisyen, 1605 öğretmen ve 1775 din görevlisi olmak üzere toplam 3662 katılımcının anketi geçerli kabul edilmiştir. Çalışma sonucunda elde edilen veriler SPSS 23,0 istatistik programılla incelenmiştir. Çalışmada anlamlılık düzeyi $\mathrm{p}<0,05$ olarak belirlenmiştir. Analiz sonucunda mesleki tükenmişlik ve mesleki tutum arasında ters yönlü yüksek düzeyde bir korelasyon görülmüştür. Bunun yanında medeni durum, yaş, hizmet süresi, cinsiyet, yaşanılan şehir ve eğitim seviyesi gibi değişkenler ile mesleki 
tutum ve tükenmişlik arasında kurumdan kuruma değişmekle birlikte anlamlı bir ilişki olduğu tespit edilmiştir. Yerleşim yeri, unvan ve mesleği seçme nedeninin ise mesleki tutum ve tükenmişlik açısından tüm kurumlarda benzer bir etkiye sahip olduğu görülmüştür. Ulaşılan sonuçlar araştırmacı tarafından yorumlanmış, ayrıca sonuçlardan hareketle bazı önerilerde bulunulmuştur.

\section{Anahtar Kelimeler}

Din Psikolojisi, Din Eğitimi, Din Öğreticisi, Mesleki Tutum, Tükenmişlik

\section{Giriş}

Her insanın beslenme, barınma, güvende olma gibi fiziksel ihtiyaçlarının yanında hayatına anlam verme, dünyada yapılanların karşılığını bekleme gibi birtakım manevi ihtiyaçları da vardır. Dolayısıyla her insan bu dünyadaki varlığının bir amacı olup olmadığını, varsa bu amacının ne olduğunu merak eder ve buna kendince cevap bulmaya çalışır. Bu tür sorulara en tatmin edici cevaplar dinden gelmektedir. İnsan, doğduğunda hazır bulduğu, ailesinden ve çevresinden görüp öğrendiği bir dine inansa da bu tür soruları sormaya başladığında çevreden gördüğü, duyduğu dinî bilgiler bazen yeterli olmamaktadır. Bundan dolayı dini daha iyi bildiğini düşündüğü kişilere başvurarak sorularına cevap arayabilmektedir.

Bütün kurumsal dinlerde insanların dinle ilgili sorularına cevap veren din adamları veya din bilginleri bulunur. Türkiye'de din görevliliği hizmetini büyük oranda Diyanet İşleri Başkanlığında (DİB) imam-hatip, müezzin-kayyım, Kur'an kursu öğreticisi, vaiz vb. hizmetlerde çalışanlar, din eğitim ve öğretim faaliyetini ise Millî Eğitim Bakanlı̆̆ında (MEB) din kültürü ve ahlak bilgisi (DKAB) ve imamhatip lisesi (IHL) meslek dersleri öğretmenleri, dinî yükseköğretim kurumlarındaki (YÖK) öğretim elemanları ve yine Diyanet İşleri Başkanlığının ilgili personeli karşılamaktadır. Ancak gerek din adamlarının/din görevlilerinin gerekse din eğitimini meslek olarak yürütenlerin dinî konularda soru soran insanlara sadece sözlü olarak bilgiyi aktarmaları yeterli değildir; din adına konuşan ve dinî bilgi verenlerin yaşantılarında rol model olmaları beklenmektedir. Yani din eğitim ve öğretimiyle ilgilenenlerin dinin emir ve yasaklarına uygun bir yaşam sürmeleri yaptıkları işte etkili olmaları için bir gerekliliktir. Çünkü ancak bu özelliklere sahip kişiler insanlara bilgi vermenin yanında örnek olabilir ve rehberlik yapabilir. Bunun için de öncelikle dinlerini ve dinî bir mahiyete sahip olan mesleklerini severek ve isteyerek yapmalı, mesleklerine ve insanlara karşı olumlu duygulara sahip olmalıdırlar. Ülkemizde son on yıldır, daha önce hiç olmadı̆̆ı kadar, dinle ilgili mesleklerde personele ihtiyaç artmıştır. Din görevlisine ihtiyacın artmasında birçok yeni cami ve Kur'an kursu yapılması ve Kur'an kurslarına olan talebin artması; din eğitimcisine olan ihtiyacın artmasında ise imam hatip okullarına giden öğrencilerin artması, ilk ve ortaöğretimdeki Temel Dini Bilgiler, Peygamberimizin Hayatı, Kur'an-1 Kerim gibi derslerin öğrenciler ve veliler tarafından ilgiyle karşılanması gibi sebepler etkili olmuştur. Bunun sonucu olarak din görevlisi ve din eğitimcisi yetiştiren kurumlara da ilgi artmış, böylece imam hatip 
liseleri ve ilahiyat/İslami ilimler fakültelerinin hem öğrenci hem de öğretmen/akademisyen sayısı artmıştır.

Türkiye'de din eğitimi ve din hizmetlerini yürütecek personeli yetiştiren kurumların başında imam hatip okulları ile ilahiyat/İslami ilimler fakülteleri gelmektedir. İmam hatip okulları ortaokul ve lise düzeyinde eğitim vererek hem halka yönelik din eğitim-öğretim faaliyeti sürdürmekte hem de Diyanet İşleri Başkanlığının din hizmetleri sınıfında yer alan imam-hatip, müezzin-kayyım ve Kur'an kursu öğreticilerinin büyük kısmını yetiştirmektedir. Dinî yükseköğretim kurumları ön lisans ve lisans düzeyinde eğitim vererek bir taraftan Diyanet İşleri Başkanlı̆̆ı ve Millî Eğitim Bakanlığının din eğitim ve din hizmetleri alanında ihtiyaç duyduğu personeli yetiştirmekte, diğer taraftan din alanında akademik düzeyde çalışmalar gerçekleştirmektedir. Bununla birlikte; Millî Eğitim Bakanlığı ilköğretimden liseye kadar tüm okul türlerinde genel bir din eğitimi vermenin yanında imam hatip okulları ve diğer okullardaki seçmeli dersler yoluyla dinî içerikli bir eğitim de vermektedir. Diyanet İşleri Başkanlığı da din alanında eğitim ve hizmet vermenin yanında halkı dinî konularda irşat etmeye ve her türlü dinî açıklama, yayın ve fetvalarla halka yol göstermeye çalışmaktadır.

Türkiye'de din eğitimi ve hizmetleri alanında en çok personel istihdam eden kurumlar DİB, MEB ve dinî yükseköğretim kurumlarıdır. ${ }^{2}$ Bu kurumlarda çalışan personel, unvanları birbirinden çok farklı da olsa atanmak ve görevlerini sürdürmek için belli bir din eğitimi almakta ve görevlerini icra ederken de benzer şekilde insanlara din eğitimi vermekte, dinî konularda yol göstermektedir. Bu kişiler bir taraftan mesleklerini diğer devlet memurları gibi belirli kurallar çerçevesinde ve geçim sağlamak amaciyla yürütürken diğer taraftan mesleklerinin kendilerine dinî bir sorumluluk da yüklediğinin bilincinde olarak görevlerini öbür dünyayı kazanmaya bir vesile olarak görmektedir. ${ }^{3}$ Ayrıca Türkiye gibi halkının çoğu Müslüman olan bir ülkede insanlar, bu meslekleri yapanları sadece belirli hizmetleri veren bir devlet memuru olarak değil aynı zamanda kendilerine hayatın her alanında yol gösteren ve örnek olan kişiler olarak düşünmektedir. ${ }^{4}$

\section{Tutum ve Mesleki Tutum}

"Tutum, belli bir kavram, durum veya insanlara karşı doğumdan itibaren öğrenilen, olumlu ya da olumsuz tepki verme eğilimidir. Bu açıdan ilgi ve tutumlar birbirlerine benzemektedir. Ancak ilgiler kişinin kendi faaliyetleriyle ilgili duygu veya tercihleriyle sınırlıdır. Yani davranışa dönüşmek zorunda değildir. Tutumlar ise, davra-

1 Diyanet İşleri Başkanlı̆̆ı (DỉB), "2020 Yılı 4-B Sözleşmeli (KKÖ, İ-H, M-K) Alımı Sınavı (Revize)” (Erişim 11 Haziran 2021).

2 İşilanlarım, İlahiyat Mezunları Ne İş Yapar? ilahiyat İş Olanakları Nelerdir? (Erişim 11 Haziran 2021). Ali Akpınar, "Diyanet", (Erişim 10 Haziran 2021).

4 Ahmet Ali Çanakçı, “Cami Cemaatinin Din Görevlilerine Bakışı: Balıkesir Örneği”, Balıkesir Üniversitesi ilahiyat Fakültesi Dergisi 1/2 (Aralık 2015), 274-275. 
nışa dönüşme eğilimine sahiptir." ${ }^{5}$ Ayrıca "bir yönelime tutum denilebilmesi için uzunca bir zaman sürekli bir şekilde görülmesi gerekir. Bunun yanında tutum düşüncelerle ve duygularla sınırlı değildir. Tutumlar kendilerini düşünce ve inanç olarak gösteren zihinsel, duyguları kapsayan duyuşsal ve dişardan görülebilen etkinlikleri içeren davranışsal öğelere sahiptir." Thurstone tutumu, "psikolojik bir objeye yönelen olumlu ya da olumsuz bir yoğunluk sıralaması ve derecelendirmesi olarak tanımlarken" Allport, "deneyim ve yaşantılar sonucunda oluşan, yöneldiği tüm durum veya nesnelere karşı kişinin davranışlarını etkileyen ve yönlendiren bilişsel veya duygusal hazırlık durumu" olarak tanımlamıştır. ${ }^{8}$ Yapılan tanımlardan anlaşıldığına göre tutumlar bireye ait olup, açıkça gözlenemese bile davranışlar ve hareketlerden önce gelerek bunlara rehberlik eden yapılardır. ${ }^{9} \mathrm{Bu}$ tanımlar birlikte düşünüldügünde en genel anlamıla tutumu insanın herhangi bir kişi nesne veya olaya ilişkin davranış gösterme eğilimi şeklinde tanımlamak mümkündür. Dolayısıyla insan, olumlu tutuma sahip olduğu şeylere karşı yaklaşma ve destek olma eğilimi, olumsuz tutuma sahip olduğu şeylere karşı ise uzaklaşma veya ilgisiz olma eğilimi gösterir. İnsanlar doğuştan tutumlara sahip değildir. Yani tutumlar, öğrenme ve yaşantı yoluyla kazanılır, değişir ve gelişir..$^{10}$

"Mesleki tutum, bir meslekte çalışanların o mesleğe yönelik duygusal eğilimleridir. Meslek mensuplarının, mesleğinin işlevleri ve toplum içindeki konumu hakkındaki duygu ve düşünceleri, onların mesleki tutumlarını oluşturur. Bireyin mesleğine ilişkin geliştirdiği tutum, onun mesleğe karşı vaziyet alışını belirler. Din görevlilerinin de kendi mesleklerine karşı belli bir biçimde ve belli bir yönde tepki göstermeye hazır olmaları mesleki tutumlarının bir göstergesidir."11 Din görevlilerinin mesleki tutumu, onların meslekle ilgili yaşantı, tecrübe ve deneyimleri sonucu oluşmuştur. Din görevlisinin mesleğiyle ilgili geçirdiği yaşantılarla oluşan mesleki tutumunun duygusal, zihinsel ve davranışsal boyutları bulunur. Mesleği sevme ya da sevmeme gibi duygular, mesleki tutumunun duygusal boyutunu oluşturur. Meslekle ilgili düşünce ve bilgileri mesleki tutumun bilişsel (zihinsel) boyutunu meydana getirmektedir. Mesleki tutumun davranış boyutu ise, duygusal ve bilişsel boyutlarına uygun

5 Ata Tezbaşaran, Likert Tipi Ölçek Geliştirme Kılavuzu (Ankara: Türk Psikologlar Derneği Yayınları, 1997), 1.

6 Doğan Cüceloğlu, İnsan ve Davranışı (İstanbul: Remzi Kitabevi, 2004), 521; Hüseyin Peker, Din Psikolojisi (Samsun: Sönmez Matbaa ve Yayınevi, 1993), 88; Mustafa Naci Kula, "Bedensel Engellilere Yönelik Tutumlar ile Dini Tutumlar Arasındaki İlişki Üzerine Bir Araştırma”, İslami Araştırmalar Din Psikolojisi Özel Saylst 19/3 (2006), 511-525.

7 Louis Leon Thurstone, "Attitudes can be Measured", American Journal of Sociology 33 (1928), 529-531.

8 Gordon W. Allport, "Attitudes”, A Handbook of Social Psychology, ed. Carl Murchison (Worcester: Clark University Press, 1935), 798.

9 Sibel Ayşen Arkonaç, Sosyal Psikoloji (ìstanbul: Alfa Basın Yayın Dağııım, 2001), 158.

10 Çiğdem Kağıtçıbaşı, İnsan ve İnsanlar (İstanbul: Evrim Yayınları, 1988), 84; Adnan Erkuş, Psikoloji Terimleri Sözlüğü (İstanbul: Doruk Yayınları, 1994), 85.

11 Mevlüt Kaya - Bayramali Nazıroğlu, "Din Görevlilerinin Mesleki Tutum ve Motivasyon Düzeylerini Etkileyen Bazı Faktörler”, Ondokuz Mayıs Üniversitesi İlahiyat Fakültesi Dergisi 26-27 (2008), 29-30. 
olarak yapılan mesleki faaliyetler ve işlerdir. ${ }^{12}$ Bireyin bir mesleğe ilişkin tutumu o meslekteki başarısı ve doyumunu etkilemektedir. Söz konusu meslek insanlara eğitim vermeyle ilgili olduğunda ise, konunun önemi daha da artmaktadır. ${ }^{13}$

Sağlıklı toplumları oluşturan en önemli unsurlardan birisi, hiç şüphesiz eğitim sistemi ve bu sistemin etkin bir şekilde işletilmesidir. Bu süreçte ise nitelikli bir öğretmenin, din görevlisinin ve akademisyenin sadece alanı ile ilgili bilgi ve becerilere sahip olması yeterli değildir; bunun yanı sıra mesleğine yönelik tutumunun da olumlu olması gerekir. Eğitimcilerin mesleklerine karşı olan tutumları mesleğini yerine getirmede büyük önem taşımaktadır.

\section{Tükenmişlik ve Mesleki Tükenmişlik}

İnsanlar hayatlarının her döneminde küçük veya büyük bazı olumsuz durumlarla karşılaşabilirler. Bu durumlar hem aile ve yakın çevrede hem de meslek yaşamında ortaya çıkabilir. İnsan mesleğini yaparken işin kendisinden kaynaklanan problemler yaşayabileceği gibi işyerinde diğer çalışanlarla ve hizmet verdiği kişilerle kişisel sorunlar da yaşayabilir. Bu tür sorunlarla karşı karşıya gelen kişiler öncelikle bunları kendi imkânlarıyla aşmaya çalışırlar, başarılı olamadıklarında arkadaşlarından veya profesyonel destek veren kişilerden de yardım alabilirler. Ancak bazen de kişiler bu tür sorunlarla başa çıkmayı başaramaz ve kendilerini enerjisiz ve tükenmiş hissedebilirler. İş hayatında motivasyonu düşen ve çaresizlik içinde kalan kişiler günümüzde meşhur bir kavram olan "mesleki tükenmişlik" durumuyla karşı karşıya kalabilirler.

İlk olarak 1970'li yıllarda Amerika'da ortaya çıkan tükenmişlik kavramı, ilk defa psikanalist Freudenberger tarafından 1974 yılında tanımlanmıştır. ${ }^{14}$ Ona göre tükenmişlik, "yıpranma başarısız olma, gücün ve enerjinin azalması veya bireyin iç kaynaklarında meydana gelen tükenme durumudur." ${ }^{15}$ Tükenmişlik konusunda en önemli çalışmaları yapan ve bu kavramın bilim dünyasında tanınır olmasını sağlayan kişi C. Maslach'tır ve bu alanda en yaygın kullanılan tanım da ona aittir. Maslach'a göre tükenmişlik "işi gereği sürekli diğer insanlarla yüz yüze çalışmak durumunda olan ve yoğun duygusal taleplere maruz kalan kişilerde görülen fiziksel bitkinlik, geçmeyen yorgunluk, hâlsizlik, umutsuzluk ve çaresizlik duygularının yapılan işe, diğer insanlara ve hatta hayata olumsuz tutumlarla yansıması ile oluşan bir sendrom"dur. ${ }^{16}$ Ayrıca genellikle tükenmişlik yaşayan kişiler yaydıkları olumsuz enerjiyle

12 Mevlüt Kaya, Din Eğitiminde İletişim ve Dini Tutum (İstanbul: Etüt Yayınları, 1998), 46.

13 Özlem Çakır vd., "Mersin Üniversitesi Eğitim Fakültesi 1999-2000 Yılı Öğretmenlik Meslek Bilgisi Programının (ÖMBP) Çeşitli Değişkenler Açısından Değerlendirilmesi", Mersin Üniversitesi Araștırma Fonu Saymanlığı (ÖÇ) 2000-1 Nolu Araştırma Projesi, 2000; Gülbahar Korkmaz, illköğretim Okullarinda Görev Yapan Öğretmenlerin Okul Yaşam Kalitesini Algılama Düzeyleri ve Mesleki Tutumlarının İncelenmesi (Adana: Çukurova Üniversitesi Sosyal Bilimler Enstitüsü, Yüksek Lisans Tezi, 2009), 35.

14 Kadir Ardıç - Sema Polatc1, "Tükenmişlik Sendromu Akademisyenler Üzerinde Bir Uygulama (GOÜ Örneği)", Gazi Üniversitesi İktisadi ve İdari Bilimler Fakültesi Dergisi 10/2 (Aralık 2008), 70.

15 Herbert J. Freudenberger, "Staff burn-out", Journal of Social Issues 30 (1974), 159-161.

16 Christina Maslach - Susane E. Jackson, "The Measurement of Experienced Burnout", Journal of Occupational Behaviour 2 (1981), 99. 
çevrelerindeki diğer kişilerin de tükenmişlik yaşamasına sebep olur; yani bir anlamda tükenmişlik bulaşıcıdır. Bundan dolayı bir işyerinde bazı çalışanlar tükenmişlik yaşıyor ve bu durum bir süredir devam ediyorsa diğer çalışanlar da kısa süre içinde bitkinlik, umutsuzluk, anksiyete gibi tükenmişlik belirtileri gösterebilir. ${ }^{17}$

"Her birey zaman zaman kapasitesini zorlayan kırılmalar yaşamaktadır ve bunlar kişiyi başa çıkma çabasına sevk eder. Kişinin kontrolü tekrar sağlamak ve anlam kaybına engel olmak için başvurduğu her çaba bir başa çıkma etkinliğidir. Bunlar bazen seküler bazen de dinî olabilir; yani birey fiziksel, psikolojik, sosyal ve manevi başa çıkma yöntemlerinin hepsini bu süreçte kullanabilir. ${ }^{18}$

Bu çalışmada Diyanet İşleri Başkanlığında (imam-hatip, müezzin-kayyım, Kur'an kursu öğreticisi ve vaiz), Millî Eğitim Bakanlığında (din kültürü ve ahlak bilgisi ve imam-hatip lisesi meslek dersleri öğretmeni) ve dinî yükseköğretim kurumlarında (araştırma görevlisi, öğretim görevlisi, Dr. öğretim üyesi, doçent ve profesör) çalışanların çeşitli değişkenlere göre mesleki tutum ve tükenmişlik düzeylerinin ortaya konması ve din psikolojisi açısından bunların değerlendirilmesi amaçlanmıştır.

Din eğitimcileri ile ilgili yapılmış mesleki tutum ve tükenmişlik çalışmalarında genellikle bir veya birkaç şehir örneklem alınarak yapılmış ve kurumların sadece biriyle sinırlı tutulmuştur. Ancak din alanında hizmet veren personel söz konusu olduğunda DİB, MEB ve YÖK bünyesinde eğitim veren dinî yükseköğretim kurumları (ilahiyat ve İslami ilimler fakülteleri) arasında çok yakın bir ilişki söz konusudur. Bundan dolayı bu çalışma söz konusu kurumlarda din alanında görev yapan personelin tamamını karşılaştırmalı olarak araştırması açısından önem arz etmektedir. Ayrıca evren olarak yedi ayrı bölgedeki büyükşehirlerde görev yapan personelin seçilmesi de çalışmanın verilerini Türkiye'ye genelleme imkânı vermesi açısından önemlidir. Çalışma din alanında hizmet veren üç önemli kurumda çalışanların mesleki tutum ve tükenmişlik düzeylerini karşılaştırmalı olarak ortaya koyması sayesinde, bahsedilen üç kurumun yöneticileri ve bu konuyla ilgili politika üretenler için yararlı veriler sunması ve personel memnuniyetinin artırılarak o personelden hizmet alan halkın beklenti düzeyinin yükseltilmesi gibi çabalara veri sağlaması açısından da önem arz etmektedir.

Çalışmanın ana hipotezi "Din eğitimci ve öğreticilerinin mesleki tutumları ile mesleki tükenmişlikleri arasında ters yönlü yüksek düzeyde bir korelasyon vardır." şeklindedir. Çalışmanın yardımcı hipotezleri ise şunlardır:

Din eğitimci ve öğreticilerinin;

1. Görev yaptıkları kurum ile dinî/mesleki tutum ve tükenmişlikleri arasında ilişki vardir.

2. Medeni durumları ile dinî/mesleki tutum ve tükenmişlikleri arasında ilişki vardır.

3. Cinsiyetleri ile dinî/mesleki tutum ve tükenmişlikleri arasında ilişki vardır.

17 Sona Khaim Alizada, Akademik Personelin Tükenmişlik Açısından Değerlendirilmesi ve İş Doyumuna Yönelik Bir Araştırma (İstanbul: İstanbul Aydın Üniversitesi, Sosyal Bilimler Enstitüsü, Yüksek Lisans Tezi, 2017), 6.

18 Merve Kocaman, Şiddete Uğrayan Kadınlarda Dinî Başa Çıkma (Erzincan Örneği) (Bursa: Uludağ Üniversitesi, Sosyal Bilimler Enstitüsü, Yüksek Lisans Tezi, 2019), 74. 
4. Eğitim düzeyleri ile dinî/mesleki tutum ve tükenmişlikleri arasında ilişki vardır.

5. Yaşları ile dinî/mesleki tutum ve tükenmişlikleri arasında ilişki vardır.

6. Hizmet süreleri ile dinî/mesleki tutum ve tükenmişlikleri arasında ilişki vardır.

7. Yaşadıkları şehir ile dinî/mesleki tutum ve tükenmişlikleri arasında ilişki vardır.

8. Yerleşim yerleri ile dinî/mesleki tutum ve tükenmişlikleri arasında ilişki vardır.

9. Görev yaptıkları unvan ile dinî/mesleki tutum ve tükenmişlikleri arasında ilişki vardir.

10. Mesleği seçme nedenleri ile dinî/mesleki tutum ve tükenmişlikleri arasında ilişki vardır.

\section{Yöntem}

\subsection{Araştırmanın Modeli}

$\mathrm{Bu}$ araştırma nicel araştırma yöntemleri arasında yer alan ilişkisel tarama modeliyle gerçekleştirilmiştir. Bu modelin tercih edilme sebebi birden fazla sayıdaki değişken arasında karşılıklı değişimin varlığını ve/veya derecesini belirlemeye yardımCı olmasıdır. Değişkenler arasındaki ilişkiler karşılaştırma ve korelasyon olmak üzere iki model olarak ele alınır. Karşılaştırmada, oluşturulan grupların değişkenlere göre farklılaşıp farklılaşmadığına bakılırken korelasyonda ise değişkenlerin birbirleriyle ilişkisinin derecesi ve yönü ortaya konmaktadır. ${ }^{19}$

\subsection{Evren ve Örneklem}

Çalışmanın evrenini MEB, DíB ve dinî yükseköğretim kurumlarında çalışan öğretmen, din görevlisi ve akademisyenler oluşturmaktadır. Çalışmanın örneklemi, küme örnekleme yoluyla seçilmiştir. Bu yöntem evrendeki bütün kümelerin tek tek (bütün elemanlarıyla birlikte) eşit seçilme şansına sahip olduklarında yapılı. ${ }^{20} \mathrm{Bu}$ çalışmada evreni en iyi şekilde temsil edeceği düşünülerek; Türkiye'nin farklı bölgelerinden göç alan, köklü dinî yükseköğretim kurumlarına sahip olan ve çok sayıda MEB ve DİB personelinin bulunduğu Adana, Ankara, Diyarbakır, Erzurum, İstanbul, İzmir, Samsun'dan toplam 3662 birey örneklem olarak seçilmiştir. Örneklemde DKAB ve İHL meslek dersleri öğretmenleri, müezzin-kayyım, imam-hatip, vaiz ve Kur'an kursu öğreticileri ile profesör, doçent, Dr. öğretim üyeleri, öğretim görevlileri ve araştırma görevlileri yer almaktadır.

\subsection{Veri Toplama Araçları}

\subsubsection{Kişisel Bilgi Formu}

Kişisel bilgi formu araştırmanın amacına uygun olarak araştırmacı tarafından hazırlanmıştır. Form, çalışılan kurum, medeni durum, cinsiyet, yaş, eğitim düzeyi, hizmet süresi, şehir, yerleşim yeri, unvan ve mesleği seçme nedeni olmak üzere toplam on maddeden oluşmaktadır.

\footnotetext{
19 Niyazi Karasar, Bilimsel Araştırma Yöntemi (Ankara: Nobel Yayın Dağıtım, 1999), 8-82.

20 Karasar, Bilimsel Araştırma Yöntemi, 114.
} 


\subsubsection{Mesleki Tutum ölçeği}

Uygulanacak ölçekler belirlenirken öncelikle Türkiye'de birçok çalş̧mada kullanılan mesleki tutum ve tükenmişlik ölçekleri incelenmiştir. Bu kapsamda Şaban Çetin'in geliştirdiği 35 maddelik iç tutarlılık katsayı (Cronbach alpha) değeri 0,95 olan mesleki tutum ölçeği ile ${ }^{21}$ Mehmet Üstüner tarafından geliştirilen 35 maddelik iç tutarlılık katsayı (Cronbach alpha) değeri 0,93 olan mesleki tutum ölçeği ${ }^{22}$ esas alınarak 23 maddelik bir mesleki tutum ölçeği oluşturulmuştur. Örneklemin tamamı dinî mesleklerde çalışanlardan oluştuğu için ölçeklerde yer alan maddelere mesleğin dinî yönünü ön plana çıkaran ve mesleğe yönelik dinî tutumları belirlemeyi amaçlayan ifadeler eklenerek mesleki tutum ölçeğine son şekli verilmiştir. Likert şeklinde oluşturulan ölçekte 23 madde bulunmaktadır. Ölçekte bazı maddeler olumsuz olarak ifade edilmiş, bunlar ters olarak kodlanmıştır. Ölçekten alınabilecek en yüksek puan 95 , en düşük puan ise $23^{\prime}$ tür. Puanların yükselmesi mesleki tutumun da yükseldiği/olumlu olduğu anlamına gelmektedir. Ölçeğe son şekli verildikten sonra örneklemden alınan bir gruba uygulanmış, iç tutarlılık katsayı (Cronbach alpha) değerinin 0,82 olduğu görülmüş ve ölçeğin güvenilir olduğuna karar verilmiştir.

\subsubsection{Maslach Tükenmişlik ölçeği}

Mesleki tükenmişlik ölçeği olarak ise Türkiye'de birçok çalışmada kullanılmasından dolayı sonuçlar arasında karşılaştırma imkânı vermesi ve mevcut çalışmaya da uygunluğu sebebiyle Maslach Tükenmişlik Ölçeği kullanılmıştır. Her iki ölçek de "her zaman, çoğu zaman, bazen, çok nadir ve hiçbir zaman" şeklinde seçeneklerin yer aldığı 5'li Likert tipi olarak hazırlanmıștır. Verilen cevaplar 1'den 5'e doğru numerik olarak kodlanmış, ters olarak ifade edilen maddelerde ise puanlama da ters olarak yapılmıştır. Ölçekler uygulandıktan sonra analizlere geçilmeden önce tekrar güvenirlik analizine bakılmış ve buna göre uygulanan ölçeklerden mesleki tükenmişlik ölçeğinin Cronbach's alfa değerinin 0,871; mesleki tutum ölçeğinin ise 0,875 olduğu görülmüştür.

\subsection{Verilerin Toplanması ve Analizi}

Anket uygulama aşamasında ölçeklerin başına çalışmaya katılımın tamamen isteğe bağlı olduğu ve elde edilen bilgilerin bu çalışma dışında başka amaçlarla kullanılmayacağı yönünde açıklama metni ve demografik bilgileri ölçen maddeler eklenmiştir. Anket formuna son şekli verildikten sonra 06.09.2018 tarihli etik kurul onayının ve kurumlardan gerekli izinlerin alınmasının ardından ölçekler örneklem grubuna uygulanmıştır.

Anketler toplam 3770 kişiye uygulanmış, bunlardan eksik doldurulan, tüm sorulara aynı cevap verildiği için okumadan doldurulduğu düşünülen 108 anket değer-

${ }_{21}$ Şaban Çetin, "Öğretmenlik Mesleği Tutum Ölçeğinin Geliştirilmesi (Geçerlik ve Güvenirlik Çalışmas1)", Gazi Üniversitesi Endüstriyel Sanatlar Eğitim Fakültesi Dergisi 18 (2006), 28-37.

22 Mehmet Üstüner, "Öğretmenlik Mesleğine Yönelik Tutum Ölçeğinin Geçerlik ve Güvenirlik Çalışmas1", İnönü Üniversitesi, Kuram ve Uygulamada Eğitim Yönetimi 45/45 (2006), 109-127. 
lendirme dışı tutulmuştur. Geçerli kabul edilen 3662 anket değerlendirilmeye alınmış ve veriler SPSS programında analiz edilmiştir.

Uygulanan anketler üzerinde istatistiksel çözümlemelere geçmeden önce, demografik değişkenler gruplandııılmış ardından verilerin istatistiksel çözümlemeleri bilgisayar ortamında gerçekleştirilmiştir. Bu aşamada araştırma grubunu oluşturan kişilerin demografik özelliklerinin (kurum, medeni durum, cinsiyet, yaş, eğitim seviyesi, hizmet süresi, şehir, yerleşim yeri, unvan ve mesleği seçme nedeni) betimleyici frekans ve yüzde dağılımları çıkarılmıştır. Örneklem içerisinde normal dağılım özelliği gösteren dağılımlar için parametrik analiz teknikleri kullanılmıştır. Bu bağlamda iki alt kategoriden oluşan gruplarda bağımsız örneklem t-testi, üç ve daha fazla alt kategoriden oluşan gruplarda varyans analizi (ANOVA) uygulanmışıı. Varyans analizi sonucunda gruplar arası farklılıklar ve farklılaşmanın yönü post-hoc testlerinden Scheffe ve Tukey HSD kullanılarak tespit edilmiştir.

Anketlerin unvanlara göre dağılımı ise şu şekildedir: Diyanet İşleri Başkanlığı personeli; 208'i müezzin-kayyım, 804 imam-hatip, 104 vaiz ve 659 Kur'an kursu öğreticisi olmak üzere 1775 kişi. Millî Eğitim Bakanlığı personeli benzer unvanlarda çalıştıkları ve meslekleriyle ilgili tutum ve tükenmişlikleri görev yaptıkları okul türü ve öğrenci yapısına göre değişebileceği için çalıştıkları okullara göre ayrılmıştır. Buna göre ulaşılan 1662 öğretmenin 482'si imam-hatip okullarında, 782'si ilköğretimde, 341'i diğer ortaöğretim kurumlarında çalışmaktadır. Dinî yükseköğretimde çalışanların ise 63'ü araştırma görevlisi, 34'ü öğretim görevlisi, 52'si dr. öğretim üyesi, 54'ü doçent ve 79'u profesör kadrosunda görev yapmaktadır.

\section{Araştırma Bulguları ve Değerlendirme}

\subsection{Demografik Bilgiler}

Tablo 1: Çalışmaya Katılan Adayların Demografik Bilgileri

\begin{tabular}{l|l|l|l}
\hline \multirow{2}{*}{ Değişkenler } & & $\mathbf{N}$ & Yüzde \\
\cline { 2 - 4 } & YÖK & 282 & 7,7 \\
\cline { 2 - 4 } & MEB & 1605 & 43,8 \\
\cline { 2 - 4 } & DỉB & 1775 & 48,5 \\
\hline \multirow{4}{*}{ Cinsiyedeni durum } & Bekâr & 761 & 20,8 \\
\cline { 2 - 4 } & Evli & 2901 & 79,2 \\
\hline \multirow{4}{*}{ Yaş } & Kadın & 1629 & 44,5 \\
\cline { 2 - 4 } & Erkek & 2033 & 55,5 \\
\hline \multirow{5}{*}{ Eğitim düzeyi } & $18-34$ yaş arası & 1241 & 33,9 \\
\cline { 2 - 4 } & $35-44$ yaş arası & 1265 & 34,5 \\
\cline { 2 - 4 } & $45-54$ yaş arası & 877 & 23,9 \\
\cline { 2 - 4 } & 55 üstü & 279 & 7,6 \\
\hline & Lise & 263 & 7,2 \\
\cline { 2 - 4 } & Ön lisans & 1024 & 28,0 \\
\hline
\end{tabular}




\begin{tabular}{|c|c|c|c|}
\hline & Lisans & 1896 & 51,8 \\
\hline & Lisansüstü & 479 & 13,1 \\
\hline \multirow[t]{5}{*}{ Hizmet süresi } & $1-5 \mathrm{y} 1 \mathrm{l}$ & 1113 & 30,4 \\
\hline & $6-10 \mathrm{yll}$ & 773 & 21,1 \\
\hline & $11-15$ y1l & 599 & 16,4 \\
\hline & $16-25$ y1l & 502 & 13,7 \\
\hline & 25 üstü & 675 & 18,4 \\
\hline \multirow[t]{7}{*}{ Şehir } & İstanbul & 873 & 23,8 \\
\hline & Ankara & 611 & 16,7 \\
\hline & İzmir & 603 & 16,5 \\
\hline & Adana & 374 & 10,2 \\
\hline & Diyarbakır & 276 & 7,5 \\
\hline & Samsun & 493 & 13,5 \\
\hline & Erzurum & 432 & 11,8 \\
\hline \multirow[t]{3}{*}{ Yerleşim yeri } & Köy & 335 & 9,1 \\
\hline & İlçe & 1663 & 45,4 \\
\hline & İl & 1664 & 45,4 \\
\hline \multirow[t]{12}{*}{ Unvan } & İmam & 804 & 45,3 \\
\hline & Müezzin & 208 & 11,7 \\
\hline & Kur'an kursu öğreticisi & 659 & 37,1 \\
\hline & Vaiz & 104 & 5,9 \\
\hline & İlköğretim öğr. & 782 & 48,7 \\
\hline & İmam-hatip öğr. & 482 & 30,0 \\
\hline & Diğer lise öğr. & 341 & 21,2 \\
\hline & Profesör & 79 & 28 \\
\hline & Doçent & 54 & 19,1 \\
\hline & Dr. öğretim üyesi & 52 & 18,4 \\
\hline & Öğretim görevlisi & 34 & 12,1 \\
\hline & Araştırma görevlisi & 63 & 22,3 \\
\hline \multirow[t]{5}{*}{ Mesleği seçme nedeni } & Çok sevmek & 1769 & 48,3 \\
\hline & Dinî yönü & 890 & 24,3 \\
\hline & Saygın ve itibarlı olması & 426 & 11,6 \\
\hline & Aile ve yakınların istekleri & 214 & 5,8 \\
\hline & Katsayı vb. mücbir sebepler & 363 & 9,9 \\
\hline
\end{tabular}

Tabloda 1'de görüldüğü araştırmaya katılanların \%7,7'si (282 kişi) yükseköğretim kurumlarında, \%43,8'i MEB'de ve \%48,5'i Di̇B'de çalışmaktadır. Örneklemin \%79,2'sini (2901) evliler, \%20,8'ini (761) bekârlar oluşturmaktadır. Erkek katılımcıların oranı \%55,5 (2033) ile kadınların oranından (\%44,5 1629 kişi) daha fazladır. Tabloya göre çalışmaya katılanların büyük oranda 35-44 yaşları arasında olduğu (1265 kişi), sonra 
ise genç yetişkinlik denilen 18-34 yaş arası kişilerin geldiği (1241) görülmektedir. Daha sonra ileri yetişkinlik diyebileceğimiz 45-54 arası (877 kişi); son olarak ise 55 üstü yaştaki kişiler (279 kişi) gelmektedir. Eğitim düzeyi olarak birinci sırada 1896 kişiyle lisans mezunları gelmekte sonra 1024 kişiyle ön lisans mezunları, 479 kişiyle lisansüstü mezunları ve 263 kişiyle lise mezunları sıralanmaktadır. Tabloda çalışanların hizmet süresiyle ilgili dağılımları ise şu şekildedir: 1-5 yll arası 1113 kişi $(\% 30,4)$, 6-10 yıl arası 773 kişi (\%21,1), 11-15 yll arası 599 kişi (\%16,4), 16-25 yıl arası 502 kişi (\%13,7), 25 üstü 675 kişi $(18,4)$. Yaşadıkları şehir açısından bakıldığında örneklemin çoğu İstanbul'da (873 kişi \%23,8) yaşamaktadır. Sonra 611 kişiyle Ankara $(\% 16,7), 603$ kişiyle İzmir (\%16,5), 493 kişiyle Samsun (\%13,5), 432 kişiyle Erzurum (\%11,8), 374 kişiyle Adana $(\% 10,2)$ ve 276 kişiyle Diyarbakır $(\% 7,5)$ gelmektedir. Yerleşim yerine bakıldığında il (1664 kişi) ve ilçede (1663 kişi) yaşayanların \%45,4 ile aynı oranda olduğu, köyde yaşayanların ise (335 kişi) \%9,1 ile en düşük orana sahip olduğu görülmektedir. Dinî yükseköğretim, MEB ve DỉB kurumları çalışanlarının kurum içindeki örneklem sayısına göre dağılımları şu şekildedir. Profesör Dr. 79 kişi (\%28), doçent Dr. 54 kişi $(\% 19,1)$, Dr. öğretim üyesi 52 kişi $(\% 18,4)$, öğretim görevlisi 34 kişi (\%12,1), araştırma görevlisi 63 kişi (\%22,3); imam-hatip öğretmeni 482 kişi (\%30), diğer lise DKAB öğretmeni 341 kişi $(\% 21,2)$, ilköğretim DKAB öğretmeni 782 kişi (\%48,7); vaiz 104 kişi $(\% 5,9)$, Kur’an kursu öğreticisi 659 kişi $(\% 37,1)$, imam-hatip 804 kişi $(\% 45,3)$ ve müezzin-kayyım 208 kişi $(\% 11,7)$. Örneklem grubunun mesleği seçme nedenine göre dağılımına bakıldığında 1769 kişiyle mesleği sevdiği için seçenler $(\% 48,3)$ ilk sırada gelmekte, onları 890 kişiyle mesleği dinî yönü için seçenler $(\% 24,3)$ takip etmekte, daha sonra 426 kişiyle saygın ve itibarlı bir meslek olduğu için seçenler gelmekte (\%11,6), 363 kişiyle katsayı uygulaması vb. mücbir sebeplerle seçenler $(\% 9,9)$ ve 214 kişiyle aile ve yakınlarının istekleriyle seçenler $(\% 5,8)$ ise son sıralarda gelmektedir.

Genel olarak bakıldığında örneklem sayısının değişkenlere dengeli bir şekilde dağıldığı ve her bir değişkenin analiz yapmaya yetecek sayıda işaretlendiği görülmektedir. Ayrıca genel anlamda değişkenlerin evreni yansıtacak şekilde olduğu sonucu çıkarılabilir. Örneğin erkek ve kadın sayısının birbirine yakın olduğu, imam-hatip ve müezzin-kayyımların tamamının erkek olması sebebiyle erkek sayısının biraz daha fazla olduğu görülmektedir. Son yıllarda din görevlisi, din eğitimci ve öğreticisinin fazla sayıda atanmasının da örneklemde kıdemi daha az ve yaşı genç kişilerin fazla olmasını sağladığı düşünülmektedir.

\subsection{Mesleki Tutum ve Tükenmişlikle İlgili Bulgular}

\subsubsection{Kurumlara Göre Mesleki Tutum ve Tükenmişlik Düzeyleriyle İlgili Bulgular}

Tablo 2: Kurumlara Göre Mesleki Tutum ve Tükenmişlik Düzeyleriyle İlgili Bulgular

\begin{tabular}{|c|c|c|c|c|c|c|c|}
\hline & Kurum & $\mathbf{N}$ & $\mathrm{X}$ & Ss & $F$ & $P$ & Anlamli Fark \\
\hline Mesleki & YÖK & 282 & 4,29 & ,50949 & 128,614 & ,000 & YÖK-MEB* \\
\hline Tutum & MEB & 1605 & 4,09 & 58964, & & & DİB-MEB* \\
\hline
\end{tabular}




\begin{tabular}{|c|c|c|c|c|c|c|c|}
\hline & DİB & 1775 & 4,39 & ,52032 & & & \multirow[t]{2}{*}{ DİB-YÖK* } \\
\hline & Toplam & 3662 & 4,25 &, 56989 & & & \\
\hline \multirow{4}{*}{$\begin{array}{l}\text { Mesleki } \\
\text { Tükenmişlik }\end{array}$} & YÖK & 282 & 1,76 & ,45339 & \multirow[t]{4}{*}{96,654} & \multirow[t]{4}{*}{,000 } & \multirow{4}{*}{$\begin{array}{l}\text { MEB-YÖK* } \\
\text { MEB-Dİ* } \\
\text { YÖK-DİB* }\end{array}$} \\
\hline & MEB & 1605 & 1,84 & ,52851 & & & \\
\hline & DİB & 1775 & 1,61 & ,46623 & & & \\
\hline & Toplam & 3662 & 1,72 & ,50631 & & & \\
\hline
\end{tabular}

* Ortalaması yüksek olanlar önce verilmiştir.

Kurumlara göre çalışanların mesleki tutum ortalama puanları DİB 4,39; dinî yükseköğretim 4,29; MEB 4,09; bütün çalışanların 4,25'tir. Tek yönlü varyans analizine göre kurumlar arasında mesleki tutum açısından anlamlı bir fark $(p=, 000)$ vardır. Buna göre Diyanet İşleri Başkanlığı çalışanlarının tutumları diğer iki kuruma göre anlamlı ölçüde yüksektir. Ayrıca dinî yüksek öğretim çalışanları da Millî Eğitim Bakanlığı çalışanlarından daha yüksek mesleki tutum puanlarına sahiptir. Mesleki tükenmişlikle ilgili sonuçlara bakıldığında mesleki tutuma benzer bir durumun olduğu görülmektedir. Buna göre en düşük tükenmişliğe DİB çalışanları $(1,61)$ sahipken en yüksek tükenmişliğe ise MEB çalışanları $(1,84)$ sahiptir. Tüm kurumlar arasında anlamlı bir fark $(p=, 000)$ ortaya çıkmıştır. Bu sonuçlar "Din eğitimci ve öğreticilerinin görev yaptıkları kurum ile dinî/mesleki tutum ve tükenmişlikleri arasında ilişki vardır." hipotezinin desteklendiğini açıkça göstermektedir. Bu sonuçların ortaya çıkmasında en önemli faktörlerden biri Diyanet çalışanlarının eğitim seviyesinin diğer kurumlarda çalışanlara göre daha düşük ve beklentilerinin de genel olarak daha az olmasıdır. Millî Eğitim Bakanlığında çalışan DKAB/IHL meslek dersleri öğretmenleri ise en az lisans mezunu olmalarına rağmen meslekte yükselme veya k1dem arttıkça ücret ve özlük haklarında bir iyileşme olmadığı için tükenmişlikleri oldukça yüksektir. Dinî yükseköğretim kurumları ise birbirinden farklı imkânlara sahip çalışanlardan oluştuğu için farklı tükenmişlik düzeyleri orta çıkmıştır. Çünkü profesör ve doçent unvanında çalışanların ücret ve diğer hakları öğretim görevlileri ve araştırma görevlilerine göre çok daha iyidir. Bu durum unvan ile mesleki tutum ve tükenmişlik ilişkisinde daha açık olarak görülebilecektir.

\subsubsection{Medeni Duruma Göre Mesleki Tutum ve Tükenmişlik Düzeyleriyle İlgili Bulgular}

Tablo 3: Medeni Duruma Göre Mesleki Tutum ve Tükenmişlik Düzeyleriyle İlgili Bulgular

\begin{tabular}{|c|c|c|c|c|c|c|c|c|}
\hline Kurum & & Medeni & $\mathrm{N}$ & $\mathrm{X}$ & Ss & $F$ & $P$ & Anlamlı \\
\hline \multirow[t]{4}{*}{ YÖK } & Mesleki & Evli & 245 & 4,33 & ,48862 & \multirow{2}{*}{,234 } & \multirow{2}{*}{,016 } & \multirow{2}{*}{ Evli-Bekâr* } \\
\hline & Tutum & Bekâr & 37 & 4,07 & ,59096 & & & \\
\hline & \multirow{2}{*}{$\begin{array}{l}\text { Mesleki } \\
\text { Tükenmişlik }\end{array}$} & Evli & 245 & 1,72 & 44295 & \multirow{2}{*}{,436 } & \multirow{2}{*}{,000 } & \multirow{2}{*}{ Bekâr-Evli* } \\
\hline & & Bekâr & 37 & 2,02 & ,43606 & & & \\
\hline \multirow[t]{3}{*}{ MEB } & Mesleki & Evli & 1183 & 4,10 & ,58041 & \multirow{2}{*}{4,523} & \multirow{2}{*}{ 293 } & \multirow{2}{*}{ Yok } \\
\hline & Tutum & Bekâr & 422 & 4,06 & 61471 & & & \\
\hline & Mesleki & Evli & 1183 & 1,83 &, 52045 & ,978 & ,082 & Yok \\
\hline
\end{tabular}




\begin{tabular}{|c|c|c|c|c|c|c|c|c|}
\hline & Tükenmişlik & Bekâr & 422 & 1,88 & ,54918 & & & \\
\hline \multirow[t]{4}{*}{ DİB } & \multirow{2}{*}{$\begin{array}{l}\text { Mesleki } \\
\text { Tutum }\end{array}$} & Evli & 1473 & 4,38 &, 52427 & \multirow{2}{*}{5,184} & \multirow{2}{*}{, 014} & \multirow{2}{*}{ Bekâr-Evli* } \\
\hline & & Bekâr & 302 & 4,46 & 49633 & & & \\
\hline & \multirow{2}{*}{$\begin{array}{l}\text { Mesleki } \\
\text { Tükenmişlik }\end{array}$} & Evli & 1473 & 1,62 & ,47022 & \multirow{2}{*}{1,590} & \multirow{2}{*}{, 042} & \multirow{2}{*}{ Evli-Bekâr* } \\
\hline & & Bekâr & 302 & 1,56 & ,44392 & & & \\
\hline \multirow[t]{4}{*}{ TÜM } & \multirow{2}{*}{$\begin{array}{l}\text { Mesleki } \\
\text { Tutum }\end{array}$} & Evli & 2901 & 4,26 &, 56136 & \multirow{2}{*}{5,124} & \multirow[b]{2}{*}{,091 } & \multirow{2}{*}{ Yok } \\
\hline & & Bekâr & 761 & 4,22 & ,60056 & & & \\
\hline & \multirow{2}{*}{$\begin{array}{l}\text { Mesleki } \\
\text { Tükenmişlik }\end{array}$} & Evli & 2901 & 1,71 & ,49927 & \multirow{2}{*}{4,113} & \multirow[b]{2}{*}{, 021} & \multirow{2}{*}{ Bekâr-Evli* } \\
\hline & & Bekâr & 761 & 1,76 & ,53082 & & & \\
\hline
\end{tabular}

* Ortalaması yüksek olanlar önce verilmiştir.

Medeni durum ile mesleki tutum arasındaki ilişki incelendiğinde dinî yükseköğretim çalışanlarında evlilerin (evli 4,33 bekâr 4,07 p=,016), DİB çalışanlarında bekârların daha yüksek bir ortalamaya sahip olduğu (evli 4,38 bekâr 4,46 p=,014), MEB çalışanlarında ise ortalamaların birbirine oldukça yakın olduğu (evli 4,10 bekâr 4,06 $\mathrm{p}=$,293) görülmüştür. Medeni duruma göre mesleki tükenmişlikte ise yükseköğretim çalışanlarında bekârların (evli 1,72 bekâr 2,02 p=,000), DİB çalışanlarında evlilerin (evli 1,62 bekâr 1,56 p=,042), anlamlı oranda tükenmişlik yaşadığı MEB çalışanlarında ise ortalamaların birbirine yakın olduğu (evli 1,83 bekâr 0,082) tespit edilmiştir. Üç kurum bir arada değerlendirildiğinde mesleki tutum puanlarında anlamlı bir fark olmadığı (evli 4,26 bekâr 4,22 p=,091), mesleki tükenmişlikte ise bekârların ortalamalarının yüksek olduğu (evli 1,71 bekâr 1,76 p=,021) görülmüştür. "Din eğitimci ve öğreticilerinin medeni durumları ile dinî/mesleki tutum ve tükenmişlikleri arasında ilişki vardır." şeklindeki hipotezin öğretmenler için desteklenmediği yükseköğretim kurumu ve DİB çalışanları için desteklendiği görülmektedir. Bu sonuçlardan hareketle evliliğin hayatta ortaya çıkan sorunlarla baş etmede yardımcı olduğu ve ailevi desteğin mesleki tükenmişlikle başa çıkmada pozitif destek sağladığı anlaşılmaktadır.

2.2.3. Cinsiyete Göre Mesleki Tutum ve Tükenmişlik Düzeyleriyle İlgili Bulgular

Tablo 4: Cinsiyete Göre Mesleki Tutum ve Tükenmişlik Düzeyleriyle İlgili Bulgular

\begin{tabular}{|c|c|c|c|c|c|c|c|c|}
\hline Kurum & & Cinsiyet & $\mathrm{N}$ & $\mathrm{X}$ & Ss & $\mathrm{F}$ & $\mathrm{P}$ & Anlamlı Fark \\
\hline \multirow[t]{4}{*}{ YÖK } & \multirow{2}{*}{$\begin{array}{l}\text { Mesleki } \\
\text { Tutum }\end{array}$} & Erkek & 245 & 4,28 & ,51096 & \multirow{2}{*}{, 546} & \multirow{2}{*}{,246 } & \multirow{2}{*}{ Yok } \\
\hline & & Kadın & 37 & 4,38 & 49712 & & & \\
\hline & \multirow{2}{*}{$\begin{array}{l}\text { Mesleki } \\
\text { Tükenmişlik }\end{array}$} & Erkek & 245 & 1,75 & ,45982 & \multirow{2}{*}{,001 } & \multirow{2}{*}{,353 } & \multirow{2}{*}{ Yok } \\
\hline & & Kadın & 37 & 1,82 & ,40893 & & & \\
\hline \multirow[t]{4}{*}{ MEB } & \multirow{2}{*}{$\begin{array}{l}\text { Mesleki } \\
\text { Tutum }\end{array}$} & Erkek & 702 & 4,05 & ,60446 & \multirow{2}{*}{1,162} & \multirow{2}{*}{,039 } & \multirow{2}{*}{ Kadın-Erkek* } \\
\hline & & Kadın & 903 & 4,11 & ,57675 & & & \\
\hline & \multirow{2}{*}{$\begin{array}{l}\text { Mesleki } \\
\text { Tükenmişlik }\end{array}$} & Erkek & 702 & 1,82 & ,52989 & \multirow{2}{*}{, 056} & \multirow{2}{*}{,057 } & \multirow{2}{*}{ Yok } \\
\hline & & Kadın & 903 & 1,87 &, 52666 & & & \\
\hline \multirow[t]{3}{*}{ DİB } & Mesleki & Erkek & 1086 & 4,31 & ,55576 & \multirow{2}{*}{53,944} & \multirow{2}{*}{, 000} & \multirow{2}{*}{ Kadın-Erkek* } \\
\hline & Tutum & Kadın & 689 & 4,52 & ,42800 & & & \\
\hline & Mesleki & Erkek & 1086 & 1,67 & ,49205 & 28,347 & ,000 & Erkek-Kadın* \\
\hline
\end{tabular}




\begin{tabular}{|c|c|c|c|c|c|c|c|c|}
\hline & Tükenmişlik & Kadın & 689 & 1,51 & ,40186 & & & \\
\hline \multirow[t]{4}{*}{ TÜM } & Mesleki & Erkek & 2033 & 4,22 & ,58013 & \multirow{2}{*}{4,332} & \multirow{2}{*}{,000 } & \multirow{2}{*}{ Kadın-Erkek* } \\
\hline & Tutum & Kadın & 1629 & 4,30 & ,55413 & & & \\
\hline & Mesleki & Erkek & 2033 & 1,73 & ,50577 & \multirow{2}{*}{ 953 } & \multirow{2}{*}{ 266 } & \multirow{2}{*}{ Yok } \\
\hline & Tükenmişlik & Kadın & 1629 & 1,71 & ,50695 & & & \\
\hline
\end{tabular}

* Ortalaması yüksek olanlar önce verilmiştir.

Cinsiyet ile mesleki tutum ortalamalarına göre yükseköğretim kurumu çalışanlarında anlamlı (erkek 4,28 kadın 4,38 p=,246) bir fark çıkmamış, MEB (erkek 4,05 kadın 4,11 p=,039) ve DİB (erkek 4,31 kadın 4,52 p=,000) çalışanlarında ise kadınların ortalaması daha yüksek çıkmıştır. Mesleki tükenmişlikte ise yükseköğretim (erkek 1,75 kadın 1,82 p=,353) ve MEB (erkek 1,82 kadın 1,87 p=,057) çalışanlarında anlamlı bir fark çıkmazken DİB çalışanlarında erkeklerin tükenmişlik ortalamaları kadınlardan anlamlı şekilde (erkek 1,67 kadın 1,51 p=,000) yüksek çıkmıştır. Üç kurum birlikte ele alındığında erkeklerin mesleki tutum ortalamaları kadınlara göre anlamlı şekilde (erkek 4,22 kadın 4,30 p=,000) düşük çıkmış, tükenmişlikte ise fark anlamlılık seviyesine (erkek 1,73 kadın 1,71 p=,266) ulaşmamıştır. Araştırma sonuçlarına göre "Din eğitimci ve öğreticilerinin cinsiyetleri ile dinî/mesleki tutum ve tükenmişlikleri arasında ilişki vardır." hipotezinin kısmen desteklendiği görülmektedir. Mesleki tükenmişliğin en önemli sebeplerinden biri de muhatap olunan insanlardır. Özellikle sürekli insanlarla ilgilenmek gereken mesleklerde çalışanlar bundan dolayı daha fazla tükenmişlik yaşamaktadır. Diyanet İşleri Başkanlığında erkekler genellikle imam ve müezzin olarak çalışırken kadınlar daha çok Kur'an kursu öğreticisi olarak çalışmaktadır. Dolayısıyla kadınlar daha az sayıda insanla muhatap olmakta ve daha az tükenmişlik yaşamaktadır. Nitekim aynı mesleği yapanlarda çoğu zaman tükenmişlik ortalamaları açısından anlamlı bir fark olmaması bu durumu ispatlamaktadır. Kadınların daha duygusal olmaları ve sık sık aile ile iş arasında kalmaları sebebiyle tükenmişlik yaşama ihtimalleri artmaktadır. Bundan dolayı anlamlılık seviyesine ulaşmasa da MEB ve dinî yükseköğretim çalışanlarında kadınlar daha fazla tükenmişlik yaşamaktadır. Buna göre cinsiyetin tükenmişlikte etkili bir faktör olduğu ancak diğer faktörlerin gerisinde kaldı̆̆ı söylenebilir.

\subsubsection{Yaşa Göre Mesleki Tutum ve Tükenmişlik Düzeyleriyle İlgili Bulgular}

Tablo 5: Yaşa Göre Mesleki Tutum ve Tükenmişlik Düzeyleriyle İlgili Bulgular

\begin{tabular}{|c|c|c|c|c|c|c|c|c|}
\hline Kurum & & Yaş & $\mathbf{N}$ & $\mathrm{X}$ & Ss & $\mathrm{F}$ & $\mathrm{P}$ & Anlamli Fark \\
\hline \multirow[t]{7}{*}{ YÖK } & Mesleki & 18-34 yaş & 58 & 4,14 & ,41149 & 2,4736 & ,062 & Yok \\
\hline & Tutum & 35-44 yaş & 91 & 4,30 & ,53324 & & & \\
\hline & & 45-54 yaş & 85 & 4,36 & 46377 & & & \\
\hline & & 55 üstü & 48 & 4,36 & ,61431 & & & \\
\hline & Mesleki & 18-34 yaş & 58 & 1,94 & ,47563 & 5,224 & ,002 & $18 / 35-45 / 54^{*}$ \\
\hline & Tükenmişlik & 35-44 yaş & 91 & 1,78 & 40650 & & & 18/35-55 üstü* \\
\hline & & 45-54 yaş & 85 & 1,67 & ,34663 & & & \\
\hline
\end{tabular}




\begin{tabular}{|c|c|c|c|c|c|c|c|c|}
\hline & & 55 üstü & 48 & 1,65 & ,59824 & & & \\
\hline \multirow[t]{8}{*}{$\overline{\mathrm{MEB}}$} & \multirow{4}{*}{$\begin{array}{l}\text { Mesleki } \\
\text { Tutum }\end{array}$} & 18-34 yaş & 711 & 4,08 & ,59541 & \multirow[t]{4}{*}{1,457} & \multirow[t]{4}{*}{,225 } & \multirow[t]{4}{*}{ Yok } \\
\hline & & 35-44 yaş & 512 & 4,07 & ,59990 & & & \\
\hline & & 45-54 yaş & 276 & 4,12 & ,57553 & & & \\
\hline & & 55 üstü & 106 & 4,18 & ,52972 & & & \\
\hline & \multirow{4}{*}{$\begin{array}{l}\text { Mesleki } \\
\text { Tükenmişlik }\end{array}$} & 18-34 yaş & 711 & 1,87 & ,53350 & \multirow[t]{4}{*}{3,844} & \multirow[t]{4}{*}{,009 } & \multirow[t]{4}{*}{ Yok } \\
\hline & & 35-44 yaş & 512 & 1,86 & ,53027 & & & \\
\hline & & 45-54 yaş & 276 & 1,78 & ,52663 & & & \\
\hline & & 55 üstü & 106 & 1,73 & ,46589 & & & \\
\hline \multirow[t]{8}{*}{$\overline{\mathrm{DIB}}$} & & 18-34 yaş & 472 & 4,44 & ,51534 & \multirow[t]{4}{*}{1,692} & \multirow[t]{4}{*}{,167 } & \multirow[t]{4}{*}{ Yok } \\
\hline & \multirow{3}{*}{ Tutum } & 35-44 yaş & 662 & 4,37 &, 52750 & & & \\
\hline & & 45-54 yaş & 516 & 4,37 & ,52062 & & & \\
\hline & & 55 üstü & 125 & 4,39 & ,49433 & & & \\
\hline & \multirow{4}{*}{$\begin{array}{l}\text { Mesleki } \\
\text { Tükenmişlik }\end{array}$} & 18-34 yaş & 472 & 1,60 & ,47761 & \multirow[t]{4}{*}{1,516} & \multirow[t]{4}{*}{0,208} & \multirow[t]{4}{*}{ Yok } \\
\hline & & 35-44 yaş & 662 & 1,59 & ,43089 & & & \\
\hline & & 45-54 yaş & 516 & 1,63 & ,49871 & & & \\
\hline & & 55 üstü & 125 & 1,66 & ,46118 & & & \\
\hline \multirow[t]{10}{*}{$\overline{\mathrm{TÜM}}$} & \multirow{5}{*}{$\begin{array}{l}\text { Mesleki } \\
\text { Tutum }\end{array}$} & 18-34 yaş & 1241 & 4,22 & ,58454 & \multirow[t]{5}{*}{3,887} & \multirow[t]{5}{*}{,009 } & $45 / 54-18 / 34^{*}$ \\
\hline & & 35-44 yaş & 1265 & 4,24 & ,57713 & & & \multirow[t]{4}{*}{55 üstü-18/34* } \\
\hline & & 45-54 yaş & 877 & 4,29 & ,54504 & & & \\
\hline & & 55 üstü & 279 & 4,30 & ,53738 & & & \\
\hline & & Toplam & 3662 & 4,25 & ,56989 & & & \\
\hline & \multirow{5}{*}{$\begin{array}{l}\text { Mesleki } \\
\text { Tükenmişlik }\end{array}$} & 18-34 yaş & 1241 & 1,77 & ,52764 & \multirow[t]{5}{*}{6,290} & \multirow[t]{5}{*}{,000 } & $18 / 34-35 / 44^{*}$ \\
\hline & & 35-44 yaş & 1265 & 1,71 & 49021 & & & \multirow[t]{4}{*}{$18 / 34-45 / 54^{*}$} \\
\hline & & 45-54 yaş & 877 & 1,68 & ,49926 & & & \\
\hline & & 55 üstü & 279 & 1,69 & ,48860 & & & \\
\hline & & Toplam & 3662 & 1,72 & ,50631 & & & \\
\hline
\end{tabular}

* Ortalaması yüksek olanlar önce verilmiștir.

Yaş ile mesleki tutum ilişkisi açısından kurumlar ayrı ayrı değerlendirildiğinde anlamlılık seviyesinde bir ilişki olmadığı, üç kurum birlikte değerlendirildiğinde ise yaş arttıkça meslekle ilgili tutumların arttığ 18-34 ile 45 yaş üstü arasında anlamlılık seviyesine ulaştığı $(p=, 009)$ görülüştür. Mesleki tükenmişlikle yaş ilişkisi incelendiğinde dinî yükseköğretim çalışanlarında yaşla birlikte tükenmişliğin anlamlı bir şekilde azaldığ 1 (18-34 yaş 1,94; 55 üstü 1,65 p=,002) ortaya çıkmıştır. Bu durumun en önemli sebeplerinden biri yükseköğretimde yaş arttıkça genellikle unvanın da artması ve unvana bağlı olarak da çalışma koşullarının iyileşmesidir. MEB çalışanlarında tükenmişlik ortalamalarının 1,73 ile 1,87 arasında DİB çalışanlarında ise 1,59 ile 1,66 arasında değiştiği ve aradaki farkın anlamlı olmadığı ortaya çıkmıştır. Üç kurum bir arada değerlendirildiğinde ise dinî yüksek öğretim kurumlarında olduğu gibi 18-34 yaş arası çalışanların tükenmişliklerinin 45 yaş üstüne göre anlamlılık seviyesinde 
daha düşük olduğu anlaşılmıştır. Bu sonuçlardan yaşın tek başına tükenmişliği çok fazla etkilemediği, yaşla birlikte çalışma koşullarında iyileşme olması durumunda tükenmişliğin azaldığı sonucuna ulaşılmaktadır. Tabloya göre "Din eğitimci ve öğreticilerinin; yaşları ile dinî/mesleki tutum ve tükenmişlikleri arasında ilişki vardır." hipotezinin büyük oranda desteklenmediği sadece yükseköğretim kurumu çalışanlarında mesleki tükenmişlikle yaş arasında anlamlılık seviyesinde bir ilişki olduğu anlaşılmaktadır.

\subsubsection{Eğitim Seviyesine Göre Mesleki Tutum ve Tükenmişlik Düzeyleriyle İlgili}

\section{Bulgular}

Tablo 6: Eğitim Seviyesine Göre Mesleki Tutum ve Tükenmişlik Düzeyleriyle İlgili Bulgular

\begin{tabular}{|c|c|c|c|c|c|c|c|c|}
\hline Kurum & & Eğitim & $\mathrm{N}$ & $\mathrm{X}$ & Ss & F & $P$ & Anlamlı Fark \\
\hline \multirow[t]{4}{*}{ YÖK } & \multirow{2}{*}{$\begin{array}{l}\text { Mesleki } \\
\text { Tutum }\end{array}$} & Lisans & 97 & 4,10 & ,53911 & \multirow{2}{*}{,253 } & \multirow{2}{*}{, 000} & \multirow{2}{*}{$\begin{array}{l}\text { Lisansüstü- } \\
\text { Lisans* }\end{array}$} \\
\hline & & Lisansüstü & 185 & 4,40 & 46243, & & & \\
\hline & \multirow{2}{*}{$\begin{array}{l}\text { Mesleki } \\
\text { Tükenmişlik }\end{array}$} & Lisans & 97 & 1,91 & ,46040 & \multirow{2}{*}{2,375} & \multirow{2}{*}{, 000} & \multirow{2}{*}{$\begin{array}{l}\text { Lisans- } \\
\text { Lisansüstü* }\end{array}$} \\
\hline & & Lisansüstü & 185 & 1,68 & ,42953 & & & \\
\hline \multirow[t]{4}{*}{ MEB } & \multirow{2}{*}{$\begin{array}{l}\text { Mesleki } \\
\text { Tutum }\end{array}$} & Lisans & 1420 & 4,10 & ,58099 & \multirow{2}{*}{3,511} & \multirow{2}{*}{, 014} & \multirow{2}{*}{$\begin{array}{l}\text { Lisans- } \\
\text { Lisansüstü* }\end{array}$} \\
\hline & & Lisansüstü & 185 & 3,98 & 64364 & & & \\
\hline & \multirow{2}{*}{$\begin{array}{l}\text { Mesleki } \\
\text { Tükenmişlik }\end{array}$} & Lisans & 1420 & 1,84 & ,52201 & \multirow{2}{*}{2,187} & \multirow{2}{*}{,188 } & \multirow{2}{*}{ Yok } \\
\hline & & Lisansüstü & 185 & 1,90 & ,57483 & & & \\
\hline \multirow[t]{8}{*}{ DİB } & Mesleki & Lise & 263 & 4,40 & ,55723 & \multirow[t]{4}{*}{6,328} & \multirow[t]{4}{*}{,000 } & \multirow{4}{*}{$\begin{array}{l}\text { Lise- } \\
\text { Lisansüstü* } \\
\text { Ön lisans- } \\
\text { Lisansüstü* }\end{array}$} \\
\hline & \multirow[t]{3}{*}{ Tutum } & Ön lisans & 1024 & 4,41 & ,49437 & & & \\
\hline & & Lisans & 379 & 4,37 & ,51735 & & & \\
\hline & & Lisansüstü & 109 & 4,18 & ,62834 & & & \\
\hline & \multirow{4}{*}{$\begin{array}{l}\text { Mesleki } \\
\text { Tükenmişlik }\end{array}$} & Lise & 263 & 1,58 & ,44429 & \multirow[t]{4}{*}{4,718} & \multirow[t]{4}{*}{,063 } & \\
\hline & & Ön lisans & 1024 & 1,59 & 47109 & & & \\
\hline & & Lisans & 379 & 1,66 & ,46802 & & & Yok \\
\hline & & Lisansüstü & 109 & 1,71 & ,44114 & & & \\
\hline \multirow[t]{10}{*}{ TÜM } & \multirow{5}{*}{$\begin{array}{l}\text { Mesleki } \\
\text { Tutum }\end{array}$} & Lise & 263 & 4,40 & ,55723 & \multirow[t]{5}{*}{55,889} & \multirow[t]{5}{*}{,000 } & \multirow{5}{*}{$\begin{array}{l}\text { Lise-Lisans* } \\
\text { Lise- } \\
\text { Lisansüstü* } \\
\text { Ön lisans- } \\
\text { Lisans* } \\
\text { Ön lisans- }\end{array}$} \\
\hline & & Ön lisans & 1024 & 4,41 & ,49437 & & & \\
\hline & & Lisans & 1896 & 4,16 & ,57715 & & & \\
\hline & & Lisansüstü & 479 & 4,19 & 60381 & & & \\
\hline & & Toplam & 3662 & 4,25 & ,56989 & & & \\
\hline & Mesleki & Lise & 263 & 1,58 & ,44429 & & & Lisans-Lise* \\
\hline & Tükenmişlik & Ön lisans & 1024 & 1,59 & ,47109 & & & Lisansüstü- \\
\hline & & Lisans & 1896 & 1,81 & ,51368 & 55,889 & ,000 & Lise* $^{*}$ \\
\hline & & Lisansüstü & 479 & 1,76 & ,50255 & & & $\begin{array}{l}\text { Lisans-Ôn } \\
\text { lisans* }\end{array}$ \\
\hline & & Toplam & 3662 & 1,72 & ,50631 & & & Lisansüstü-Ön \\
\hline
\end{tabular}

* Ortalaması yüksek olanlar önce verilmiştir.

Eğitim seviyesi ile mesleki tutum ilişkisine bakıldığında akademisyenlerde lisansüstü eğitime sahip olanlar $(4,40)$ lisans mezunu seviyesindekilerden $(4,10)$, MEB 
çalışanlarında lisans mezunları $(4,10)$ lisansüstü mezunlardan $(3,98)$ anlamlılık seviyesinde (YÖK $p=, 000$; MEB $p=, 014$ ) daha yüksek olduğu görülmüştür. DíB çalışanlarında ise lisansüstü eğitime sahip olanlar diğer eğitim seviyesindekilerden daha düşük mesleki tutuma (lise 4,40 ön lisans 4,41 lisans 4,37 lisansüstü 4,18 p=,000) sahiptir. Mesleki tükenmişlikte ise sonuçlar mesleki tutumun tersine çıkmıştır. Buna göre akademisyenlerde lisans seviyesinde eğitime sahip olanlar anlamlllık seviyesinde daha yüksek tükenmişliğe (lisans 1,91 lisansüstü 1,68 p=,000) sahipken DíB çalışanlarında lisansüstü eğitime sahip olanların tükenmişlik ortalaması (lise 1,58 ön lisans 1,59 lisans 1,66 lisansüstü 1,71 p=,063) diğer eğitim seviyesindekilere göre yüksektir. Öğretmenlerde ise eğitim seviyesinin tükenmişliği anlamlllık seviyesinde etkilemediği (lisans 1,84 lisansüstü 1,90 p=,188) sonucuna ulaşılmıştır. İnsanların eğitimleri ve nitelikleri arttıkça beklentileri de artmaktadır. Bu beklentiler karşılandıkça motivasyonları artmakta ve tükenmişlikleri düşmektedir. Bundan dolayı eğitim arttıkça unvanda genellikle buna bağlı olarak bir yükselişin yaşandığı dinî yükseköğretim kurumlarında eğitimle tükenmişlik ters orantılıyken, eğitim arttıkça unvanda değişikliğin olmadığı MEB ve DỉB çalışanlarında eğitimle tükenmişlik doğru orantılıdır. Eğitim seviyesi ile mesleki tutum arasında tüm kurumlarda, mesleki tükenmişlik arasında ise sadece dinî yükseköğretim kurumlarında anlamlı bir ilişki çıkması sebebiyle "Din eğitimci ve öğreticilerinin eğitim düzeyleri ile dinî/mesleki tutum ve tükenmişlikleri arasında ilişki vardır." hipotezinin kısmen desteklendiği söylenebilir.

\subsubsection{Hizmet Süresine Göre Mesleki Tutum ve Tükenmişlik Düzeyleriyle İlgili Bulgular}

Tablo 7: Hizmet Süresine Göre Mesleki Tutum ve Tükenmişlik Düzeyleriyle İlgili Bulgular

\begin{tabular}{|c|c|c|c|c|c|c|c|c|}
\hline Kurum & & Hizmet & $\mathbf{N}$ & $\mathrm{X}$ & Ss & $F$ & $P$ & Anlamlı \\
\hline \multirow[t]{10}{*}{ YÖK } & Mesleki & $1-5 \mathrm{yll}$ & 48 & 4,16 & 39015 & \multirow{5}{*}{3,368} & \multirow{5}{*}{,010 } & \multirow{5}{*}{ Yok } \\
\hline & \multirow[t]{4}{*}{ Tutum } & 6-10 y1l & 56 & 4,17 & 49131 & & & \\
\hline & & $11-15$ y1l & 30 & 4,47 & ,53896 & & & \\
\hline & & $16-25 \mathrm{yll}$ & 65 & 4,29 & ,45658 & & & \\
\hline & & 25 üstü & 83 & 4,39 & ,57768 & & & \\
\hline & \multirow{5}{*}{$\begin{array}{l}\text { Mesleki } \\
\text { Tükenmişlik }\end{array}$} & $1-5 \mathrm{yll}$ & 48 & 1,92 & ,45050 & \multirow[t]{5}{*}{3,928} & \multirow[t]{5}{*}{0,004} & \multirow{5}{*}{$\begin{array}{l}\text { 1/5-25 } \\
\text { üstü* }\end{array}$} \\
\hline & & 6-10 y1l & 56 & 1,83 & ,42755 & & & \\
\hline & & $11-15$ yil & 30 & 1,70 & ,42721 & & & \\
\hline & & $16-25 \mathrm{y} 1 \mathrm{l}$ & 65 & 1,77 & ,41549 & & & \\
\hline & & 25 üstü & 83 & 1,62 & ,47791 & & & \\
\hline \multirow[t]{6}{*}{ MEB } & Mesleki & $1-5 \mathrm{y} 1 \mathrm{l}$ & 714 & 4,15 & ,55567 & \multirow[t]{5}{*}{9,915} & \multirow[t]{5}{*}{,000 } & $1 / 5$ \\
\hline & \multirow[t]{4}{*}{ Tutum } & 6-10 y1l & 251 & 4,01 & ,59695 & & & $6 / 10^{*}$ \\
\hline & & 11-15 yil & 233 & 3,90 & 68157 & & & $1 / 5-$ \\
\hline & & 16-25 y1l & 205 & 4,09 & ,57237 & & & $11 / 15^{*}$ \\
\hline & & 25 üstü & 202 & 4,16 & 54793 & & & $16 / 25-$ \\
\hline & Mesleki & $1-5$ yil & 714 & 1,81 & ,51794 & 9,743 &, 000 & $11 / 15-$ \\
\hline
\end{tabular}




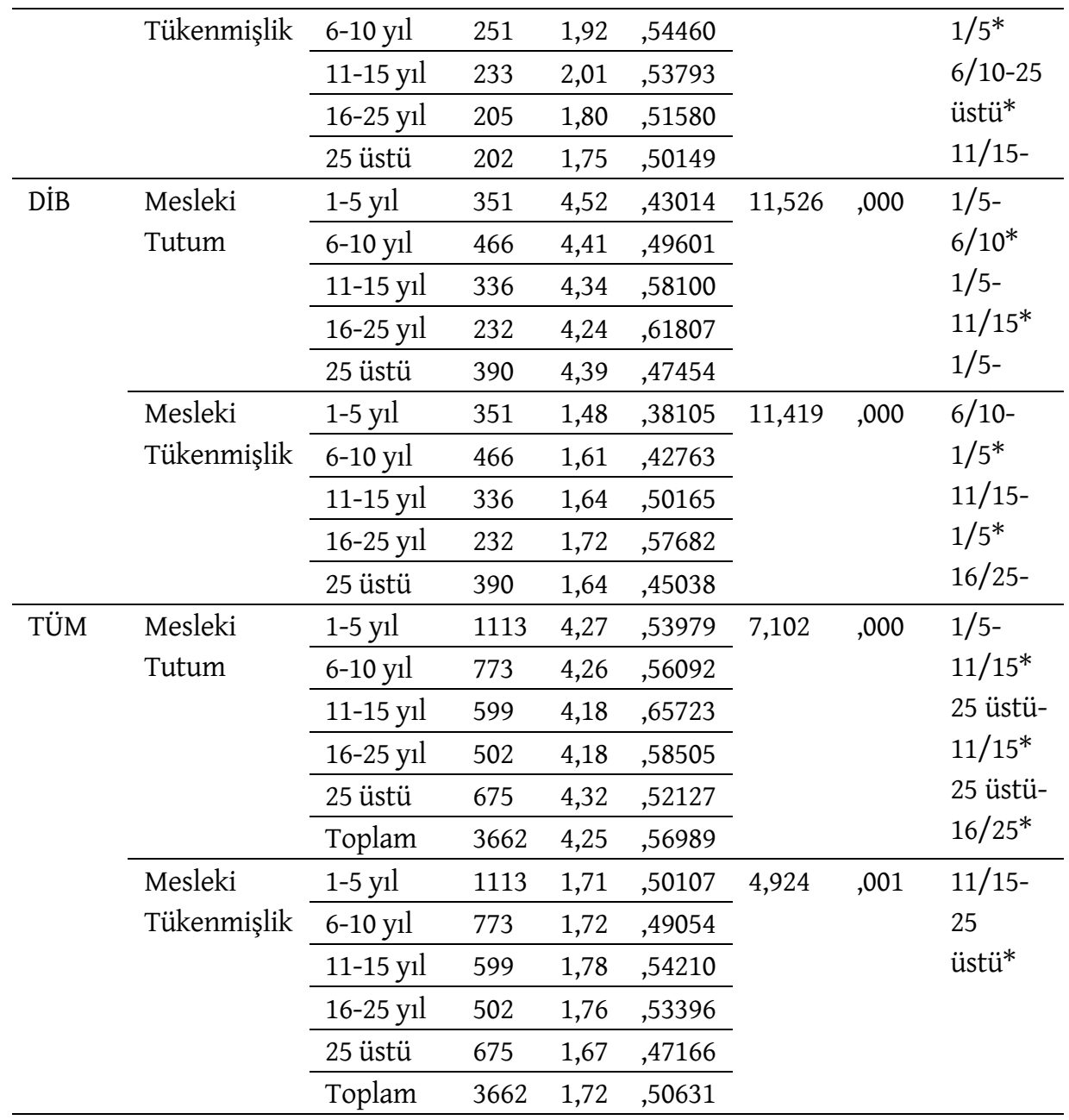

* Ortalaması yüksek olanlar önce verilmiştir.

Hizmet süresiyle mesleki tutum ilişkisi incelendiğinde MEB ve DİB çalışanlarının mesleklerinin ilk yıllarında daha olumlu tutumlara sahipken ilerleyen yıllarda mesleki tutumlarının düştüğü ancak emekliliğe yakın yıllarda ise tekrar yükseldiği görülmüştür. Yükseköğretim çalışanlarında ise ortalamalar 4,16'dan 4,39 kadar yükseldiği ancak anlamlı bir ilişkinin olmadığı tespit edilmiştir. Tükenmişlikte ise MEB çalışanlarında 1-5 yıl arası çalışanların oldukça düşük tükenmişliğe $(1,81)$ sahipken 11-15 yıl arasında en yüksek seviyeye $(2,01)$ çıtı̆̆ı ve 25 yıl üstünde ise en düşük seviyeyi gördüğü $(1,75)$ tespit edilmiştir. Buna göre öğretmenlerin mesleki motivasyonları, en verimli olmaları gereken dönemlerde en düşük seviyeye düşmektedir. Bu durum muhtemelen beklentilerin yıl geçtikçe artmasına rağmen bunların karşılanmamasından kaynaklanmaktadır. DİB çalışanlarında en düşük tükenmişliğe 1-5 yıl arası çalışanların sahip olduğu $(1,48)$ en yüksek seviyenin 16-25 yıl arasında yaşand1ğ 1 (1,72), 25 yıl üstü çalışanlarda ise biraz düşmesine rağmen $(1,64)$ yine de oldukça 
yüksek olduğu görülmüştür. Bu sonuçlar öğretmenlerle benzerlik arz etmektedir. Dinî yükseköğretim çalş̧anlarında ise yaş ilişkisinde olduğu gibi hizmet süresi arttıkça tükenmişliğin düştüğü (1-5 yıl arası 1,92; 25 üstü 1,62) ve yeni başlayanlarla en kıdemliler arasında anlamlılık seviyesine ulaştı̆̆ $(p=004)$ anlaşılmıştır. Üç kurum birlikte değerlendirildiğinde de hizmet süresi arttıkça mesleki tutumun önce düştügü, ilerleyen süreçte ise tekrar yükseldiği görülmüsstür. Mesleki tükenmişlik, mesleki tutumla uyumlu şekilde önce yükselmiş sonra ise düşüş göstermiştir. "Din eğitimci ve öğreticilerinin hizmet süreleri ile dinî/mesleki tutum ve tükenmişlikleri arasında ilişki vardır." hipotezinin mesleki tutum ile dinî yükseköğretim kurumları hariç geçerli olduğu anlaşılmaktadır.

\subsubsection{Yaşanılan Şehre Göre Mesleki Tutum ve Tükenmişlik Düzeyleriyle İlgili Bul- gular}

Tablo 8: Yaşanılan Şehre Göre Mesleki Tutum ve Tükenmişlik Düzeyleriyle İlgili Bulgular

\begin{tabular}{|c|c|c|c|c|c|c|c|c|}
\hline Kurum & & Yaşanılan & $\mathrm{N}$ & Mean & SS & F & $P$ & Anlamlı Fark \\
\hline \multirow[t]{14}{*}{ YÖK } & \multirow{7}{*}{$\begin{array}{l}\text { Mesleki } \\
\text { Tutum }\end{array}$} & Adana & 32 & 4,12 & ,74527 & \multirow[t]{7}{*}{2,461} & \multirow[t]{7}{*}{,025 } & \multirow[t]{7}{*}{ Yok } \\
\hline & & Ankara & 54 & 4,45 & ,36305 & & & \\
\hline & & Diyarbakır & 33 & 4,32 & ,45746 & & & \\
\hline & & Erzurum & 36 & 4,28 & ,51741 & & & \\
\hline & & İstanbul & 50 & 4,28 & 42989 & & & \\
\hline & & İzmir & 34 & 4,39 &, 58772 & & & \\
\hline & & Samsun & 43 & 4,14 & 44990 & & & \\
\hline & \multirow{7}{*}{$\begin{array}{l}\text { Mesleki } \\
\text { Tükenmişlik }\end{array}$} & Adana & 32 & 1,83 & 47499 & \multirow[t]{7}{*}{2,731} & \multirow[t]{7}{*}{,014 } & \multirow{7}{*}{$\begin{array}{l}\text { Samsun- } \\
\text { Ankara* }\end{array}$} \\
\hline & & Ankara & 54 & 1,61 & ,30752 & & & \\
\hline & & Diyarbakır & 33 & 1,82 & ,32655 & & & \\
\hline & & Erzurum & 36 & 1,72 & ,47637 & & & \\
\hline & & İstanbul & 50 & 1,72 &, 51748 & & & \\
\hline & & İzmir & 34 & 1,71 & ,47079 & & & \\
\hline & & Samsun & 43 & 1,95 & ,50515 & & & \\
\hline \multirow[t]{12}{*}{ MEB } & \multirow{7}{*}{$\begin{array}{l}\text { Mesleki } \\
\text { Tutum }\end{array}$} & Adana & 150 & 4,05 &, 57019 & \multirow[t]{7}{*}{1,463} & \multirow[t]{7}{*}{,117 } & \multirow[t]{7}{*}{ Yok } \\
\hline & & Ankara & 169 & 3,98 & ,65104 & & & \\
\hline & & Diyarbakır & 67 & 4,16 & ,54343 & & & \\
\hline & & Erzurum & 140 & 4,10 &, 55760 & & & \\
\hline & & İstanbul & 569 & 4,08 &, 57400 & & & \\
\hline & & İzmir & 266 & 4,15 & ,57264 & & & \\
\hline & & Samsun & 244 & 4,10 & ,63424 & & & \\
\hline & \multirow{5}{*}{$\begin{array}{l}\text { Mesleki } \\
\text { Tükenmişlik }\end{array}$} & Adana & 150 & 1,89 &, 51758 & \multirow[t]{5}{*}{1,377} & \multirow[t]{5}{*}{,220 } & \multirow[t]{5}{*}{ Yok } \\
\hline & & Ankara & 169 & 1,90 &, 55530 & & & \\
\hline & & Diyarbakır & 67 & 1,81 &, 55359 & & & \\
\hline & & Erzurum & 140 & 1,86 &, 51789 & & & \\
\hline & & İstanbul & 569 & 1,86 &, 52759 & & & \\
\hline
\end{tabular}




\begin{tabular}{|c|c|c|c|c|c|c|c|c|}
\hline & & İzmir & 266 & 1,78 & ,53630 & & & \\
\hline & & Samsun & 244 & 1,82 & ,50583 & & & \\
\hline \multirow[t]{14}{*}{ DİB } & \multirow{7}{*}{$\begin{array}{l}\text { Mesleki } \\
\text { Tutum }\end{array}$} & Adana & 192 & 4,26 & ,58894 & \multirow[t]{7}{*}{3,518} & \multirow[t]{7}{*}{,002 } & \multirow{7}{*}{$\begin{array}{l}\text { İstanbul- } \\
\text { Adana* } \\
\text { Samsun- } \\
\text { Adana* }\end{array}$} \\
\hline & & Ankara & 388 & 4,41 & ,48201 & & & \\
\hline & & Diyarbakır & 176 & 4,40 & ,49738 & & & \\
\hline & & Erzurum & 256 & 4,38 & ,54119 & & & \\
\hline & & İstanbul & 254 & 4,45 & ,43527 & & & \\
\hline & & İzmir & 303 & 4,35 & 61237 & & & \\
\hline & & Samsun & 206 & 4,45 & 43775 & & & \\
\hline & \multirow{7}{*}{$\begin{array}{l}\text { Mesleki } \\
\text { Tükenmişlik }\end{array}$} & Adana & 192 & 1,63 & ,51240 & \multirow[t]{7}{*}{2,180} & \multirow[t]{7}{*}{,042 } & \multirow[t]{7}{*}{ Yok } \\
\hline & & Ankara & 388 & 1,61 & 45092 & & & \\
\hline & & Diyarbakır & 176 & 1,56 & ,46722 & & & \\
\hline & & Erzurum & 256 & 1,63 & 42905 & & & \\
\hline & & İstanbul & 254 & 1,55 & ,37363 & & & \\
\hline & & İzmir & 303 & 1,67 & ,57396 & & & \\
\hline & & Samsun & 206 & 1,58 & ,40724 & & & \\
\hline \multirow[t]{16}{*}{ TÜM } & \multirow{8}{*}{$\begin{array}{l}\text { Mesleki } \\
\text { Tutum }\end{array}$} & Adana & 374 & 4,16 & ,60295 & \multirow[t]{8}{*}{4,561} & \multirow[t]{8}{*}{,000 } & \multirow{8}{*}{$\begin{array}{l}\text { Diyarbakır- } \\
\text { Adana* }\end{array}$} \\
\hline & & Ankara & 611 & 4,30 & ,56056 & & & \\
\hline & & Diyarbakır & 276 & 4,34 & ,51288 & & & \\
\hline & & Erzurum & 432 & 4,28 & ,55813 & & & \\
\hline & & İstanbul & 873 & 4,20 & ,55457 & & & \\
\hline & & İzmir & 603 & 4,26 & 60194 & & & \\
\hline & & Samsun & 493 & 4,25 & ,57021 & & & \\
\hline & & Toplam & 3662 & 4,25 & ,56989 & & & \\
\hline & \multirow{8}{*}{$\begin{array}{l}\text { Mesleki } \\
\text { Tükenmişlik }\end{array}$} & Adana & 374 & 1,76 & ,52594 & \multirow[t]{8}{*}{2,333} & \multirow[t]{8}{*}{,030 } & \multirow{8}{*}{$\begin{array}{l}\text { İstanbul- } \\
\text { Diyarbakır* } \\
\text { Adana- } \\
\text { Diyarbakır* }\end{array}$} \\
\hline & & Ankara & 611 & 1,69 & ,48892 & & & \\
\hline & & Diyarbakır & 276 & 1,65 & ,48941 & & & \\
\hline & & Erzurum & 432 & 1,71 & ,47406 & & & \\
\hline & & İstanbul & 873 & 1,76 & ,50598 & & & \\
\hline & & İzmir & 603 & 1,72 & ,55411 & & & \\
\hline & & Samsun & 493 & 1,73 & 48372 & & & \\
\hline & & Toplam & 3662 & 1,72 & ,50631 & & & \\
\hline
\end{tabular}

* Ortalaması yüksek olanlar önce verilmiştir.

Yaşanılan şehir ile mesleki tutum ilişkisine bakıldı̆̆ında YÖK çalışanlarının ortalamaları 4,12 ile 4,45 arasında, MEB çalışanlarını 3,98 ile 4,15 arasında değiștiği ve anlamlı (YÖK p=,0,25 MEB p=,117) bir ilişki olmadığ1; DİB çalışanlarında ise İstanbul ve Samsun'da yaşayanların ortalamalarının $(4,45)$ Adana'da $(4,26)$ yaşayanlara göre anlamlı ölçüde $(p=, 002)$ yüksek olduğu görülmüştür. Mesleki tükenmişlikte ise dinî yükseköğretim çalışanlarında Samsun'dakilerin $(1,95)$ Ankara'dakilere göre $(1,61)$ daha fazla tükenmişlik yaşadığı; MEB ve DİB çalışanlarında şehrin tükenmişlikle 
anlamlılık düzeyinde bir ilişkisinin olmadığı anlaşılmıştır. Tüm kurumlar bir arada değerlendirildiğinde Diyarbakır'dakilerin; mesleki tutum ortalamaları $(4,34)$ Adana'dakilere göre $(4,15)$ daha yüksek; mesleki tükenmişlik ortalamaları ise Diyarbakır'dakilerin (1,665); Adana, Erzurum, İstanbul ve İzmir'de çalışanlara göre (sırasıyla $1,76 ; 1,71 ; 1,76$ ve 1,72$)$ anlamlı ölçüde $(\mathrm{p}=, 030)$ daha düşük çıkmıştır. Tabloya bakıldığında "Din eğitimci ve öğreticilerinin yaşadıkları șehir ile dinî/mesleki tutum ve tükenmişlikleri arasında ilişki vardır." hipotezinin büyük oranda desteklenmediği görülmektedir. Buna göre Diyarbakır'da görev yapanlar diğer şehirlerdekilere göre mesleklerinden daha memnundur ve meslekleriyle daha iyi bir bütünleşme sağlamıştır. Meslekleriyle ilgili düşük tutuma ve yüksek tükenmişliğe sahip olan şehirlerde din alanında çalışan kişilere yönelik zaman zaman haberlere de yansıyan bazı olumsuz durumların meydana geldiği bilinmektedir. Buna ilave olarak olumsuzluk yaşanan şehirlerin diğer şehirlere göre daha fazla nüfusa sahip olduğu, yani şehirler büyüdükçe hem genel stresin hem de meslekle ilgili tükenmişliğin arttığı görülmektedir. Bu yorumu şehir merkeziyle ilçelerin karşılaştırılmasından elde edilen sonuçlar da desteklemektedir.

\begin{tabular}{|c|c|c|c|c|c|c|c|c|}
\hline Kurum & & Yerleşim & $\mathrm{N}$ & $\mathrm{X}$ & Ss & $\mathrm{F}$ & $\mathrm{P}$ & Anlamlı Fark \\
\hline \multirow[t]{6}{*}{ MEB } & \multirow{3}{*}{$\begin{array}{l}\text { Mesleki } \\
\text { Tutum }\end{array}$} & ìl merkezi & 669 & 4,04 & 60354 & \multirow[t]{3}{*}{4,716} & \multirow[t]{3}{*}{,009 } & \multirow[t]{3}{*}{ İlçe-il* } \\
\hline & & İlçe merkezi & 811 & 4,13 & ,56361 & & & \\
\hline & & Köy & 125 & 4,09 & ,65862 & & & \\
\hline & \multirow{3}{*}{$\begin{array}{l}\text { Mesleki } \\
\text { Tükenmişlik }\end{array}$} & İl merkezi & 669 & 1,88 & ,53149 & \multirow[t]{3}{*}{2,416} & \multirow[t]{3}{*}{,090 } & \multirow[t]{3}{*}{ Yok } \\
\hline & & İlçe merkezi & 811 & 1,82 &, 52130 & & & \\
\hline & & Köy & 125 & 1,84 & ,55261 & & & \\
\hline \multirow[t]{6}{*}{ DIB } & \multirow{3}{*}{$\begin{array}{l}\text { Mesleki } \\
\text { Tutum }\end{array}$} & İl merkezi & 713 & 4,34 & ,55491 & \multirow[t]{3}{*}{8,654} & \multirow[t]{3}{*}{, 000} & \multirow[t]{3}{*}{ İlçe-il* } \\
\hline & & İlçe merkezi & 852 & 4,44 & 47608 & & & \\
\hline & & Köy & 210 & 4,35 &, 55122 & & & \\
\hline & \multirow{3}{*}{$\begin{array}{l}\text { Mesleki } \\
\text { Tükenmişlik }\end{array}$} & İl merkezi & 713 & 1,64 & ,48701 & \multirow[t]{3}{*}{4,358} & \multirow[t]{3}{*}{,013 } & \multirow[t]{3}{*}{ İl-ilçe* } \\
\hline & & İlçe merkezi & 852 & 1,58 & ,45093 & & & \\
\hline & & Köy & 210 & 1,63 & ,44728 & & & \\
\hline \multirow[t]{8}{*}{ TÜM } & \multirow{4}{*}{$\begin{array}{l}\text { Mesleki } \\
\text { Tutum }\end{array}$} & İl merkezi & 1664 & 4,21 & ,58537 & \multirow[t]{4}{*}{8,477} & \multirow[t]{4}{*}{, 000} & \multirow[t]{4}{*}{ İlçe-il* } \\
\hline & & İlçe merkezi & 1663 & 4,29 & ,54360 & & & \\
\hline & & Köy & 335 & 4,25 & 60570 & & & \\
\hline & & Toplam & 3662 & 4,25 & ,56989 & & & \\
\hline & \multirow{4}{*}{$\begin{array}{l}\text { Mesleki } \\
\text { Tükenmişlik }\end{array}$} & İl merkezi & 1664 & 1,76 &, 51102 & \multirow[t]{4}{*}{6,811} & \multirow[t]{4}{*}{,001 } & \multirow[t]{4}{*}{ İl-ilçe* } \\
\hline & & İlçe merkezi & 1663 & 1,69 & ,50121 & & & \\
\hline & & Köy & 335 & 1,71 & ,49920 & & & \\
\hline & & Toplam & 3662 & 1,72 & ,50631 & & & \\
\hline
\end{tabular}


* Ortalaması yüksek olanlar önce verilmiștir.

Dinî yükseköğretim kurumlarında çalışanlar şehir merkezlerinde ikamet ettikleri için yerleşim yeri ile mesleki tutum ve tükenmişlik ilişkisine bakılamamıştır. MEB (il 4,04 ilçe 4,13 köy 4,09 p=,009) ve DİB (il 4,34 ilçe 4,44 köy 4,35 p=,000) çalışanlarında köyde ve ilde yaşayanların mesleğe yönelik tutumları ilçede yaşayanlara göre daha düşük çıkmıştır. Aynı şekilde MEB (il 1,88 ilçe 1,82 köy 1,84) ve DİB'de (il 1,64 ilçe 1,58 köy 1,63) çalışanların mesleki tükenmişlikleri en düşük ilçede yaşayanlarda çıkmıştır. Bununla birlikte MEB çalışanlarında yerleşim yeri anlamlılık seviyesinde etkili değilken $(p=, 090)$ DİB çalışanlarında anlamlılık seviyesine ulaşmaktadır ( $p=, 013)$. MEB ve DİB çalışanları birlikte değerlendirildiğinde ise ilçede yaşayanların mesleki tutum ortalamaları köyde ve ilde yaşayanlara göre anlamlılık seviyesinde daha yüksek ((il 4,21 ilçe 4,29 köy 4,25 p=,000) ve tükenmişlikleri de daha düşüktür (il 1,76 ilçe 1,69 köy 1,71 p=,001). "Din eğitimci ve öğreticilerinin yerleşim yerleri ile dinî/mesleki tutum ve tükenmişlikleri arasında ilişki vardır." şeklindeki hipotezin DİB çalışanlarında tamamen, MEB çalışanlarında kısmen desteklendiği, dinî yükseköğretim çalışanlarında ise kontrol edilemediği görülmüştür. Bu sonuçlara göre hem yerleşim merkezinin çok küçük, imkânlarının yetersiz olması hem de yerleşim merkezinin büyük, yaşamın stresli ve masrafların fazla olması mesleğe yönelik duyguları olumsuz etkilemektedir. Bundan dolayı mesleğe yönelik en olumlu duygular ilçede çalışanlarda görülmektedir.

\subsubsection{Unvana Göre Mesleki Tutum ve Tükenmişlik Düzeyleriyle İlgili Bulgular}

Tablo 10: Yerleşim Merkezine Göre Mesleki Tutum ve Tükenmişlik Düzeyleriyle İlgili Bulgular

\begin{tabular}{|c|c|c|c|c|c|c|c|}
\hline & Unvan & $\mathrm{N}$ & $\mathrm{X}$ & Ss & $\mathrm{F}$ & $\mathrm{P}$ & Anlamlı Fark \\
\hline \multirow{14}{*}{$\begin{array}{l}\text { Mesleki } \\
\text { Tutum }\end{array}$} & Araştırma görev- & 63 & 4,05 & ,43712 & \multirow[t]{14}{*}{32,235} & \multirow[t]{14}{*}{,000 } & \multirow{4}{*}{$\begin{array}{l}\text { KK öğr.-İmam* } \\
\text { İmam-Öğretmen } \\
\text { KK öğr.-Müezzin* } \\
\text { KK öğr.-Ar. Gör* }\end{array}$} \\
\hline & lisi & & & & & & \\
\hline & İlköğretim öğr. & 782 & 4,06 & ,58701 & & & \\
\hline & Düz lise öğr. & 341 & 4,07 & ,62521 & & & \\
\hline & İmam-hatip öğr. & 482 & 4,14 & ,56558 & & & \multirow{10}{*}{$\begin{array}{l}\text { KK } \\
\text { Öğretmen* öğr.- } \\
\text { Vaiz-Öğretmen* } \\
\text { Doçent- } \\
\text { Öğretmen* } \\
\text { Profesör- } \\
\text { Öğretmen* } \\
\text { İmam-Ar. Gör* } \\
\text { Vaiz-Ar. Gör* } \\
\text { Doçent-Ar. Gör* } \\
\text { Profesör-Ar. Gör* }\end{array}$} \\
\hline & Öğretim görevlisi & 34 & 4,17 & ,69122 & & & \\
\hline & Müezzin-kayyım & 208 & 4,24 &, 57899 & & & \\
\hline & Dr. öğretim üyesi & 52 & 4,30 & ,58851 & & & \\
\hline & İmam-hatip & 804 & 4,33 & ,54042 & & & \\
\hline & Vaiz & 104 & 4,38 & ,47600 & & & \\
\hline & Doçent & 54 & 4,43 & ,32650 & & & \\
\hline & Profesör & 79 & 4,43 & ,44456 & & & \\
\hline & $\begin{array}{ll}\text { Kur'an } & \text { kursu } \\
\text { öğreticisi } & \end{array}$ & 659 & 4,52 & ,45167 & & & \\
\hline & Toplam & 3662 & 4,25 & ,56989 & & & \\
\hline \multirow{2}{*}{$\begin{array}{l}\text { Mesleki } \\
\text { Tükenmişlik }\end{array}$} & Kur'an & 659 & 1,52 & ,41659 & 23,705 &, 000 & İmam-KK öğrt.* \\
\hline & öğreticisi & & & & & & Öğretmen-İmam* \\
\hline
\end{tabular}




\begin{tabular}{|c|c|c|c|c|}
\hline Vaiz & 104 & 1,55 & ,37288 & \multirow{12}{*}{$\begin{array}{l}\text { Müezzin-KK } \\
\text { öğrt.* } \\
\text { Ar. Gör.-KK öğrt.* } \\
\text { Öğretmen-KK } \\
\text { öğrt* } \\
\text { Öğretmen-Vaiz* } \\
\text { Ar. Gör.-Vaiz* }\end{array}$} \\
\hline Profesör & 79 & 1,63 & ,48956 & \\
\hline İmam-hatip & 804 & 1,66 & ,49132 & \\
\hline Doçent & 54 & 1,67 & 46781 & \\
\hline Müezzin-kayyım & 208 & 1,73 &, 50255 & \\
\hline Dr. öğretim üyesi & 52 & 1,75 &, 59636 & \\
\hline Öğretim görevlisi & 34 & 1,81 & ,47379 & \\
\hline İmam-hatip öğr & 482 & 1,84 & ,52584 & \\
\hline İlköğretim öğr. & 782 & 1,85 & ,53047 & \\
\hline Düz lise öğr. & 341 & 1,85 & ,52916 & \\
\hline $\begin{array}{l}\text { Araştırma görev- } \\
\text { lisi }\end{array}$ & 63 & 1,96 & ,44776 & \\
\hline Toplam & 3662 & 1,76 & ,68457 & \\
\hline
\end{tabular}

* Ortalaması yüksek olanlar önce verilmiştir.

Unvan ile mesleki tutum ilişkisi incelendiğinde ortalamalar küçükten büyüğe sırasıyla şu şekildedir: araştırma görevlisi, ilköğretim öğretmenliği, düz lise öğretmenliği, İmam-hatip öğretmenliği, öğretim görevlisi, müezzin-kayyım, Dr. öğretim üyesi, imam-hatip, vaiz, doçent, profesör ve Kur'an kursu öğreticisi. En yüksek mesleki tutuma sahip beş unvana sahip çalışan ile en düşük ortalamaya sahip dört unvana sahip çalışan arasında anlamlı bir ilişki $(p=, 000)$ ortaya çıkmıştır. Her üç kurumdaki çalışanların tükenmişlik puanları mesleki tutumla benzerdir ve düşükten yükseğe şu şekilde sıralanmıştır: Kur'an kursu öğreticisi, vaiz, profesör, imam-hatip, doçent, müezzin-kayyım, Dr. öğretim üyesi, öğretim görevlisi, imam hatip öğretmenliği, ilköğretim öğretmenliği, düz lise öğretmenliği, araştırma görevlisi. Genel olarak mesleki tükenmişlikte anlamlı ilişki $(p=, 000)$ en yüksek ortalamaya sahip olan öğretmenler ve araştırma görevlileri ile en düşük ortalamaya sahip olan Kur'an kursu öğreticisi ve vaizler arasında çıkmıştır. Araştırma görevlilerinin meslekle ilgili en olumsuz duygulara sahip olması, sözleşmeli olmalarından ve çalıştıkları kurumlarda en düşük unvana sahip olmalarından kaynaklanmaktadır. Diyanet'te çalışanlar aldıkları eğitime göre iyi bir konumda olmaları, yükselme firsatlarının olması ve görevleri sırasında yoğun bir alt-üst ilişkisine maruz kalmamaları sebebiyle meslekleriyle ilgili oldukça olumlu duygulara sahiptir. Yükseköğretim kurumlarında ise unvan arttıkça özlük hakları da yükseldiği için unvana bağlı olarak meslekle ilgili olumlu duygular da artmaktadır. Öğretmenler ise yükseköğrenim mezunu olmalarına rağmen beklentilerinin tam olarak karşılanmaması ve görevde yükselme vb. imkânlarının kısıtlılığı sebebiyle araştırma görevlilerinden sonra meslekle ilgili en olumsuz duygulara sahiptir. Araştırma sonuçlarına göre "Din eğitimci ve öğreticilerinin görev y aptıkları unvan ile dinî/mesleki tutum ve tükenmişlikleri arasında ilişki vardır." hipotezinin dinî yükseköğretim ve DİB çalışanlarında desteklendiği, MEB çalışanlarında ise desteklenmediği ortaya çıkmıştır. 


\subsubsection{Mesleği Seçme Nedenine Göre Mesleki Tutum ve Tükenmişlik Düzeyleriyle}

\section{İlgili Bulgular}

Tablo 11: Mesleği Seçme Nedenine Göre Mesleki Tutum ve Tükenmişlik Düzeyleriyle İlgili

\begin{tabular}{|c|c|c|c|c|c|c|c|}
\hline \multicolumn{8}{|c|}{ Bulgular } \\
\hline & Mesleği & \multirow[t]{2}{*}{$\mathrm{X}$} & \multirow[t]{2}{*}{ Ss } & \multirow[t]{2}{*}{$\mathrm{F}$} & \multirow[t]{2}{*}{$\mathrm{P}$} & \multirow{2}{*}{\multicolumn{2}{|c|}{ Anlamlı Fark }} \\
\hline & $\begin{array}{l}\text { Seçme } \mathrm{Ne}- \\
\text { deni }\end{array}$ & & & & & & \\
\hline \multirow{7}{*}{$\begin{array}{l}\text { Mesleki } \\
\text { Tutum }\end{array}$} & Çok sevmek & 1769 & 4,43 & ,42663 & \multirow[t]{7}{*}{245,087} & \multirow[t]{7}{*}{000} & \multirow{2}{*}{$\begin{array}{l}\text { Sevmek-Dinî } \\
\text { yönü* }\end{array}$} \\
\hline & Dinî yönü & 890 & 4,29 & ,50615 & & & \\
\hline & $\begin{array}{l}\text { İtibar / Say- } \\
\text { ginlık }\end{array}$ & 426 & 4,21 & ,52812 & & & $\begin{array}{l}\text { Sevmek- } \\
\text { İtibar* }\end{array}$ \\
\hline & $\begin{array}{l}\text { Yakınların } \\
\text { istekleri }\end{array}$ & 214 & 3,83 & 68794 & & & \multirow{2}{*}{$\begin{array}{l}\text { Sevmek- } \\
\text { Yakınlar* } \\
\text { Sevmek- } \\
\text { Mücbir* }\end{array}$} \\
\hline & $\begin{array}{l}\text { Mücbir se- } \\
\text { bepler }\end{array}$ & 363 & 3,59 & 68274 & & & \\
\hline & \multirow[t]{2}{*}{ Toplam } & \multirow[t]{2}{*}{3662} & \multirow[t]{2}{*}{4,25} & \multirow[t]{2}{*}{,56989 } & & & \multirow{2}{*}{$\begin{array}{l}\text { Dinî yönü- } \\
\text { Yakınlar* } \\
\text { Dinî yönü- } \\
\text { Mücbir* } \\
\text { İtibar- } \\
\text { Yakınlar* } \\
\text { İtibar- } \\
\text { Mücbir* }\end{array}$} \\
\hline & & & & & & & \\
\hline \multirow{6}{*}{$\begin{array}{l}\text { Mesleki } \\
\text { Tükenmişlik }\end{array}$} & Çok sevmek & 1769 & 1,60 & ,43901 & \multirow[t]{6}{*}{124,587} & \multirow[t]{6}{*}{, 000} & \multirow{4}{*}{$\begin{array}{l}\text { Dinî yönü- } \\
\text { Sevmek* } \\
\text { Itibar- } \\
\text { Sevmek* } \\
\text { Yakınlar- } \\
\text { Sevmek* }\end{array}$} \\
\hline & Dinî yönü & 890 & 1,70 & ,46191 & & & \\
\hline & $\begin{array}{l}\text { İtibar / Say- } \\
\text { ginlık }\end{array}$ & 426 & 1,78 & ,50243 & & & \\
\hline & $\begin{array}{l}\text { Yakınların } \\
\text { istekleri }\end{array}$ & 214 & 2,03 & ,58638 & & & \\
\hline & $\begin{array}{l}\text { Mücbir se- } \\
\text { bepler }\end{array}$ & 363 & 2,14 & ,56363 & & & $\begin{array}{l}\text { Mücbir } \\
\text { Sevmek* }^{*}\end{array}$ \\
\hline & Toplam & 3662 & 1,72 & ,50631 & & & $\begin{array}{l}\text { Yakınlar- } \\
\text { Dinî yönü* } \\
\text { Mücbir -Dinî } \\
\text { yönü* } \\
\text { Yakınlar- } \\
\text { İtibar* } \\
\text { Mücbir } \\
\text { İtibar* }\end{array}$ \\
\hline
\end{tabular}

\footnotetext{
* Ortalaması yüksek olanlar önce verilmiştir.
} 
Mesleği seçme nedeniyle mesleki tutum ve tükenmişlik arasındaki ilişki kuruma göre önemli bir değişiklik göstermediği için üç kurum birlikte değerlendirilmiştir. Buna göre bütün kurumların çalışanlarında mesleği sevdiği için seçenlerin en olumlu tutuma $(4,43)$ ve en düşük tükenmişliğe $(1,60)$ sahip olduğu görülmüştür. Sonra sırasıyla dinî yönü sebebiyle (tutum 4,29 tükenmişlik 1,70), itibarlı/saygın bir meslek olduğu için (tutum 4,21 tükenmişlik 1,78), aile ve yakınlarının istekleriyle (tutum 3,83 tükenmişlik 2,03) ve katsayı vb. mücbir sebeplerle seçenler gelmiştir. Bu sonuçlara göre en düşük mesleki tutuma $(3,59)$ ve en yüksek mesleki tükenmişliğe $(2,14)$ mesleğini "katsayı vb. kendisi dışındaki mücbir sebeplerle" seçenlerin sahip olduğu görülmüştür. Bu grupla mesleği çok sevdiği için seçenler iki aşırı ucu oluşturmuştur. Diğer sebeplerle seçenlerin ortalamaları birbirine yakındır ve mesleği çok sevdiği için seçenlerle ve katsayı vb. mücbir sebeplerle seçenlere göre oldukça ayrışmıştır. Elde edilen sonuçlara göre "Din eğitimci ve öğreticilerinin mesleği seçme nedenleri ile dinî/mesleki tutum ve tükenmişlikleri arasında ilişki vardır." hipotezinin tüm kurumlar için desteklendiği görülmüştür. Bu sonuçlardan anlaşıldığı kadarıyla kişi mesleğini ne kadar kendi iradesiyle ve sevgisine göre seçerse mesleğiyle ilgili duyguları o kadar olumlu olmakta; bunun tersi durumlarda ise mesleki motivasyonu düşmekte ve tükenmişlik yaşama ihtimali artmaktadır. Ayrıca bu verilere göre meslekle ilgili duygu ve düşünceleri en çok etkileyen hususların iş güvencesi, ilerleme imkânı, çalışma saatleri ve koşulları, kurumdan beklentiler, özlük hakları, muhatap olunan kişilerin sayısı ve niteliği, sahip olunan eğitim ve buna verilen değer olduğu anlaşılmaktadır.

Tablo 12: Mesleki Tutum ve Tükenmişlik Arasındaki İlişki

\begin{tabular}{l|l|l}
\hline & & Mesleki tutum \\
\hline Mesleki tükenmişlik & Korelasyon & $-0,731^{* *}$ \\
& Anlamlllık & 0,000 \\
\hline
\end{tabular}

** Mesleki tutum ve tükenmişlik arasında 0,01 seviyesinde negatif yönlü bir korelasyon vardir.

Tablo 12'de görüldüğü mesleki tutum ile tükenmişlik arasında anlamlılık seviyesinde $(p=, 000)$ negatif yönlü $(-0,731)$ ilişki vardır. Mesleki tutumla mesleki tükenmişlik arasındaki ilişkiye dair bu sonuçlar örneklemin mesleki tutum düzeyi arttıkça mesleki tükenmişlik düzeyinin düştüğünü göstermektedir. Buna göre çalışmanın temel hipotezi olan "Din eğitimci ve öğreticilerinin mesleki tutumları ile mesleki tükenmişlikleri arasında ters yönlü yüksek düzeyde bir korelasyon vardır.” ifadesi desteklenmiştir.

Sonuç ve Öneriler

Bu araştırmada din eğitimci ve öğreticilerinin (Millî Eğitim Bakanlığında çalışan din kültürü ve ahlak bilgisi ve imam-hatip lisesi meslek dersleri öğretmenleri, Diyanet İşleri Başkanlığında din hizmetleri sınıfında çalışanlar ve ilahiyat/İslami ilimler fakültelerinde çalışan öğretim elemanları) mesleki tutum ile tükenmişlikleri birçok değişkene göre incelenmiştir. Ulaşılan sonuçlara göre mesleki tutum ile mesleki 
tükenmişlik arasında negatif yönlü yüksek düzeyde bir ilişki vardır. Yani bireylerin mesleki tutum puanları yükseldikçe mesleki tükenmişlik puanları düşmektedir. Dolayısıyla söz konusu örneklem bağlamında çalışan bireylerin tükenmişlik duygusuna kapılmamaları ya da şayet tükenmişlik hissi yaşıyorlar ise bu kişilerin mesleklerine yönelik tutumları üzerine yoğunlaşılması ve tutumlarının yükseltilmesine yönelik çalışmalar yapılması yararlı olacaktır. Mesleki tutumu olumlu oldukça, meslekten de doyum artacak ve neticede tükenmişlik duygusundan uzaklaşılabilecektir. ${ }^{23}$

Sonuçlara göre araştırmanın temel hipotezi ve iki yardımcı hipotez doğrulanmıştır. Sekiz yardımcı hipotez ise kısmen doğrulanmış; yani kurumların bir kısmında doğrulanırken bir kısmında doğrulanmamıştır.

Mesleğe karşı en olumlu tutumlar sırasıyla Diyanet İşleri Başkanlığı, dinî yükseköğretim kurumları ve Millî Eğitim Bakanlığı çalışanlarında çıkmıştır. Mesleki tükenmişlik puanları da beklendiği gibi mesleki tutumun tersi şeklinde gerçekleşmiştir. Literatürde öğretmenliğin en fazla strese maruz kalan meslek gruplarından biri olduğu öne sürülmektedir. ${ }^{24}$ Farklı branş ve meslek gruplarında tükenmişlikle ilgili yapılan çalışmalara göre sınıf öğretmenlerinin tükenmişlik oranı 2,$00 ;{ }^{25}$ fen bilgisi öğretmenlerinde $2,07^{26}$ çıkmıştır. Bu sonuçlara bakıldığında örneklem grubumuzu oluşturan DKAB ve İHL meslek dersleri öğretmenlerinin tükenmişliğinin diğer branşlardaki öğretmenlere göre daha düşük olduğu görülmektedir. Din eğitimcileri ve öğreticilerinin tükenmişlik ortalamalarının daha düşük olduğu yani tükenmişlikle daha iyi başa çıktıkları söylenebilir.

Araştırmadan elde edilen sonuçlara göre erkeklerin mesleki tutum puanları kadınlardan daha düşüktür ve aradaki fark anlamlılık seviyesindedir. Mesleki tükenmişlikte ise erkeklerin tükenmişliği kadınlara göre daha yüksek çıkmıştır fakat fark anlamlılık seviyesine ulaşmamıştır. Farklı üniversitelerde görev yapan akademisyenlerin cinsiyetleri ile mesleki tükenmişliğin araştırıldığı çalışmalarda da ilişki olmadığı tespit edilmiştir. ${ }^{27}$ Öğretmenlerin tükenmişlikleriyle ilgili olarak yapılan bir meta analiz çalışmasına göre cinsiyet değişkeninin öğretmen tükenmişliğini çok düşük düzeyde etkilediği tespit edilmiştir. ${ }^{28}$ Analiz sonuçlarına göre medeni durumun,

23 Sena Berber, Tükenmişlik ve Iş̧ Tatmini Arasındaki İlişki: Kule Personeli Üzerine Bir Araştırma (Ankara: Gazi Üniversitesi, Sosyal Bilimler Enstitüsü, Yüksek Lisans Tezi, 2011), 85; Nurettin Küçük, Din Görevlilerinin Mesleki Yeterlilikleri ile Mesleki Tutum ve Motivasyonları Arasındaki İlişkinin İncelenmesi (Karabük İli Örneği) (Samsun: Ondokuz Mayıs Üniversitesi, Sosyal Bilimler Enstitüsü, Yüksek Lisans Tezi, 2015), 98102; Acar Arasan, Akademisyenlerde Yaşam Doyumu İş Doyumu ve Mesleki Tükenmişlik Düzeylerinin Belirlenmesine Yönelik Bir Araştırma, 102.

24 Belma Tuğrul - Eylem Çelik, "Normal Çocuklarla Çalışan Anaokulu Öğretmenlerinde Tükenmişlik", Pamukkale Üniversitesi Eğitim Fakültesi Dergisi 2/12 (2002), 1-11.

25 Mehmet Ali Öztürk, Sınıf Öğretmenlerinin İş Yükü Algısı ile Mesleki Tükenmişlik Düzeyleri Arasındaki İlişki (Kırşehir: Kırşehir Ahi Evran Üniversitesi, Sosyal Bilimler Enstitüsü, Yüksek Lisans Tezi, 2019), 35.

26 Bülent Kılınç, Fen Bilgisi Öğretmenlerinin Mesleki Tükenmişlik Düzeylerinin Bazı Değişkenler Açısından Incelenmesi (Elâzı̆̆: Fırat Üniversitesi, Eğitim Bilimleri Enstitüsü, Yüksek Lisans Tezi, 2018), 33.

27 Ardıç - Polatcı, “Tükenmişlik Sendromu Akademisyenler Üzerinde Bir Uygulama”, 87.

28 Y1lmaz İlker Yorulmaz - Yahya Altınkurt, "The Examination of Teacher Burnout in Turkey: a MetaAnalysis", Turkish Journal of Education 7/1 (2018), 34. 
mesleki tutumda anlamlı bir farka yol açmadığı görülmüştür. Mesleki tükenmişlikte ise bekârların evlilere göre anlamlılık seviyesinde daha fazla tükenmişlik yaşadığ 1 ortaya çıkmıştır. Yapılan tespitlere göre de huzurlu ve mutlu bir aile yaşamına sahip olan bireylerin, çalışma yaşamında da mutlu oldukları ve karşılaştıkları sorunlar karşısında daha az tükenmişlik duygusuna kapıldıkları gözlemlenmiştir. ${ }^{29}$ Bundan dolayı da genellikle evliler bekârlara göre daha az tükenmişlik yaşamaktadır. Farklı branşlarda ve kurumlarda görev yapan çalışanların tükenmişlik ortalamalarına bakıldığında meslek lisesi öğretmenlerinde evlilerin ortalamasının 2,74; bekârların 2,76 olduğu; ${ }^{30}$ muhasebecilerde evlilerin ortalamalarının 2,26 ile 2,79 arasında değiştiği; bekârların 2,26 ile 3,03 arasında değiştiği $i^{31}$ ve din eğitimcileri ve öğreticilerine göre yüksek olduğu ancak aradaki farkın anlamlı olmadığı görülmüştür.

Eğitim seviyesi yükseldikçe mesleki tutum ortalamaları düşmektedir. Lise ve ön lisans mezunu çalı̧̧anların ortalamaları lisans ve lisansüstü mezunu olanlara göre anlamllık seviyesinde daha yüksektir. Mesleki tutumla uyumlu şekilde eğitim seviyesi yükseldikçe mesleki tükenmişlik ortalamaları düşmektedir. Analiz sonuçlarına göre lise ve ön lisans mezunları ile lisans ve lisansüstü mezunları arasında anlamlı bir fark görülmüştür. Literatüre bakıldığında birçok çalışmada eğitim seviyesi yükseldikçe mesleki tutumun düştüğ $\ddot{u}^{32}$, tükenmişliğin ise yükseldiğgi ${ }^{33}$ görülmektedir. Buna göre aynı işi yapan kişilerde daha fazla eğitime sahip olmak tükenmişliği artırı$\mathrm{Cl}$ bir etki yapmaktadır. Bu durum büyük oranda eğitim seviyesi arttıkça, meslekle ilgili beklentilerin artması ancak karşılanmaması ile ilgilidir. Daha fazla eğitim alan kişilerin hayatta yapmak istedikleri ve beklentileri daha fazladır. Fazla idealist ve büyük amaçlara sahip olabilirler. Bununla birlikte işteki rolleri bu amaçları gerçekleştirmek için yeterli gelmemektedir. Gerçeklik ve idealleri arasındaki bu çatışma hayal kırıklığı ve tükenmişlikle sonuçlanabilir. ${ }^{34}$

29 Nihal Çetin Akbulut, Tükenmişlik Sendromu ve İş Tatmini Arasındaki İlişki (İstanbul: Marmara Üniversitesi Sosyal Bilimler Enstitüsü, Yüksek Lisans Tezi, 2010), 23.

30 Atilla Erkul, Meslek Lisesi Öğretmenlerinin Mesleki Tükenmişlik Düzeyi (İstanbul: Bahçeşehir Üniversitesi, Eğitim Bilimleri Enstitüsü, Yüksek Lisans Tezi, 2014), 34.

31 Zeliha İl, Muhasebe Meslek Mensuplarının Mesleki Tükenmişlik Durumlarının Araştırılması: Erzurum ve Erzincan Uygulaması (Erzincan: Erzincan Binali Yıldırım Üniversitesi Sosyal Bilimler Enstitüsü, Yüksek Lisans Tezi, 2018), 95-105.

32 Mine Koyuncu Şahin, Okul Öncesi Öğretmenlerinin Öz Güvenleri ve Mesleki Tutumlarının İncelenmesi (Afyon: Afyon Kocatepe Üniversitesi, Sosyal Bilimler Enstitüsü, Yüksek Lisans Tezi, 2015), 90-92; Kaya - Nazıroğlu, "Din Görevlilerinin Mesleki Tutum ve Motivasyon Düzeylerini Etkileyen Bazı Faktörler", 43-44.

33 Erkul, Meslek Lisesi Öğretmenlerinin Mesleki Tükenmişlik Düzeyi, 37; İl, Muhasebe Meslek Mensuplarının Mesleki Tükenmişlik Durumlarının Araştırılması, 99-105; Nazım Bayrakdar, Din Kültürü ve Ahlak Bilgisi Öğretmenlerinin Mesleki Tükenmişlik Algıları (Kayseri: Erciyes Üniversitesi, Sosyal Bilimler Enstitüsü, Doktora Tezi, 2014), 92-93.

34 Yasemin Çağlıyan, Tükenmişlik Sendromu ve İş Doyumuna Etkisi (Devlet ve Vakıf Üniversitelerindeki Akademisyenlere Yönelik Alan Araştırması, (Kocaeli: Kocaeli Üniversitesi Sosyal Bilimler Enstitüsü, Yüksek Lisans Tezi, 2007), 19-20. 
Din eğitimcileri ve öğreticilerinin tümü bir arada değerlendirildiğinde yaş ilerledikçe mesleğe karşı tutumun yükseldiği, aradaki farkın 18-34 yaş arası ile 45 yaş üstündekiler arasında anlamllık seviyesine ulaştı̆̆ görülmektedir. Tükenmişliğin ise yaş arttıkça genel olarak düştüğü görülmüştür. Yaş ile tükenmişlik arasındaki ilişki daha çok meslek tecrübesi ve hayatın içinde edinilen birtakım tecrübelerle anlamlı ve tutarlı hâle gelmektedir. Örneğin çalışanların yaşlandıkça tükenmişliğe daha dirençli hâle geldiklerini ortaya koyan araştırmalar, bunun nedenini çalışma hayatında edinilen tecrübelere, iş yaşamının ve hayatın gerçeklerini daha iyi kavramış olmalarına, iş ve kariyer beklentilerinin gençlik yıllarına göre nispeten azalmasına bağlamaktadır. ${ }^{35}$

Araştırma sonuçlarına göre hizmet süresi arttıkça mesleki tutumun önce düştügü̈, ilerleyen süreçte tekrar arttı̆̆ görülmüştür. Mesleki tükenmişlik ise mesleki tutumla uyumlu şekilde önce yükselmiş sonra ise düşmüştür. Hizmet süresi ile mesleki tutum ve tükenmişlik arasında farklı sonuçlar çıkmakla birlikte genellikle anlam11 bir ilişkinin olmadığ ${ }^{36}$ görülmüştür. Ayrıca yapılan bir meta analiz çalışmasında da tükenmişlik ile hizmet süresi ilişkisinin düşük olduğu görülmüştür. ${ }^{37}$ Çalsşmalardan elde edilen sonuçların farkllığı ve ilişkinin düşük olduğu sonucundan hareketle genel olarak hizmet süresi ile mesleki tutum ve tükenmişlik arasında belirgin bir ilişki olmadığı söylenebilir.

Yaşanılan şehre göre mesleki tutum açısından Diyarbakır'dakilerin ortalamalarının Adana'dakilere göre daha yüksek; mesleki tükenmişlik açısından ise Diyarbakır'dakilerin ortalamalarının İstanbul, Adana, İzmir ve Erzurum'dakilere göre daha düşük olduğu ortaya çıkmıştır. Genellikle konuyla ilgili yapılan çalışmalarda tek bir il evren olarak seçildiğinden iller arası karşılaştırma yapılmamıştır.

Araştırma sonuçlarına göre ilçede yaşayanların mesleki tutum ortalamalarının köyde ve ilde yaşayanlara göre anlamlllık seviyesinde daha yüksek ve tükenmişliklerinin de daha düşük olduğu görülmüştür. Yapılan bazı çalışmalarda yerleşim yerinin etkili olmadığ ${ }_{1}{ }^{38}$ bazı çalışmalarda ise bu çalışmaya benzer şekilde büyükşehirde yaşayanların mesleki tutumlarının diğerlerinden daha düşük olduğ $\mathrm{u}^{39}$ görülmüş̧ür.

Unvan ile mesleki tutum ilişkisine göre en düşük mesleki tutuma araştırma görevlileri sahiptir. Daha sonra sırasılla öğretmenler, öğretim üyeleri ve din görevlileri gelmektedir. En yüksek tutuma Kur'an kursu öğreticileri sahiptir. Mesleki tükenmişlik puanları ise büyük oranda mesleki tutuma benzemektedir. Düşükten başlayarak sırasıyla Kur'an kursu öğreticileri, vaiz, profesör, imam, doçent ve müezzin gelmektedir.

35 Ahmet Günay, Kabin Ekiplerinde İş Doyumu ve Tükenmişlik Sendromu (Eskişehir: Anadolu Üniversitesi, Sosyal Bilimler Enstitüsü, Yüksek Lisans Tezi, 2016), 62.

${ }^{36}$ Küçük, Din Görevlilerinin Mesleki Yeterlilikleri ile Mesleki Tutum ve Motivasyonları Arasındaki İlişkinin Incelenmesi.

37 Yorulmaz -Altınkurt, "The Examination of Teacher Burnout in Turkey: a Meta-Analysis", 34.

38 Küçük, Din Görevlilerinin Mesleki Yeterlilikleri ile Mesleki Tutum ve Motivasyonları Arasındaki ílişkinin Incelenmesi, 78.

39 Ahmet Doğan, Din Görevlilerinin Mesleki Aidiyetleri, Mesleki Tükenmişlik Tutumları ve Hizmet İçi Eğitime Bakışları (Ankara: Ankara Üniversitesi, Sosyal Bilimler Enstitüsü, Doktora Tezi, 2013). 
Öğretmenler ve araştırma görevlileri ise en yüksek tükenmişliğe sahip çalışanlardır. Ulaşılan sonuçlara göre DỉB çalışanları ile dinî yükseköğretim kurumlarında öğretim üyesi kadrosunda çalışanlar mesleklerinden en memnun grubu oluşturmaktadır. Öğretmenler ise diğer kurumlarda çalışanlara göre meslekleriyle ilgili çok daha olumsuz duygulara sahiptir. Akademisyenlerle ilgili bazı çalışmalarda unvanın mesleki tükenmişlikte etkili olmadığı ${ }^{40}$ sonucuna ulaşılırken bazı çalışmalarda ise bu çalışmaya benzer şekilde araştırma görevlilerinin en yüksek tükenmişlik ortalamalarına sahip olduğ $u^{41}$ görülmüştür. Öğretmenlerle ilgili çalışmalarda ise bu çalışmaya benzer şekilde din kültürü ve ahlak bilgisi öğretmenlerinin ortaokul ve lisede çalışmalarına göre tükenmişliklerinin değişmediğ ${ }^{42}$ ancak din kültürü ve ahlak bilgisi öğretmenlerinin ve din görevlilerinin diğer öğretmenlere ve farklı meslek mensuplarına göre daha az tükenmişlik yaşadığ ${ }_{13}^{43}$ tespit edilmiştir. Bu sonuçlardan din eğitimci ve öğreticilerinin genel olarak diğer mesleklerden daha az tükenmişlik yaşadığı ancak kendi içlerinde tükenmişlik ve tutum ortalamalarında önemli farklar olduğu sonucuna ulaşılmaktadır.

Mesleği seçme nedenine göre üç kurumun çalışanları benzer özellikler taşımaktadır. Buna göre mesleği katsayı vb. mücbir sebeplerle seçenler meslekleriyle ilgili en olumsuz duygulara sahipken mesleği sevdiği için seçenler en olumlu duygulara sahiptir. Genel olarak mesleği seçmede kişinin rolü ne kadar fazlaysa meslekle ilgili duyguları da o kadar olumlu olmaktadır. Konuyla ilgili yapılan çalışmalara bakıldığında mesleğini isteyerek ve manevi nedenlerle seçenlerin diğer nedenlerle seçenlere göre daha yüksek mesleki tutuma ve daha düşük tükenmişliğe sahip olduğu ortaya çıkmıştır. ${ }^{44}$

\section{Öneriler}

1. Din eğitimci ve öğreticilerinin görev yapacakları şehirlerde dine uzak hatta karşı kişilerin de bulunabileceği göz önüne alınarak bilgilendirilmeleri ve bir sorun

40 Başak Nur Acar Arasan, Akademisyenlerde Yaşam Doyumu İş Doyumu ve Mesleki Tükenmişlik Düzeylerinin Belirlenmesine Yönelik Bir Araştırma, (Uşak: Uşak Üniversitesi, Sosyal Bilimler Enstitüsü, Yüksek Lisans Tezi, 2010), 110-111.

41 Ardıç - Polatc1, "Tükenmişlik Sendromu Akademisyenler Üzerinde Bir Uygulama", 82.

42 Bayrakdar, Din Kültürü ve Ahlak Bilgisi Öğretmenlerinin Mesleki Tükenmişlik Algıları, 95.

43 Erkul, Meslek Lisesi öğretmenlerinin Mesleki Tükenmişlik Düzeyi; İl, Muhasebe Meslek Mensuplarının Mesleki Tükenmişlik Durumlarının Araştırlmasl; Ener Boyar, Türkiye'de Muhasebe Meslek Mensuplarının Mesleki Tükenmişlik Durumlarının Araştırılması (Sakarya: Sakarya Üniversitesi, Sosyal Bilimler Enstitüsü, Doktora Tezi, 2011); Öztürk, Sinıf Öğretmenlerinin İş Yükü Algısı ile Mesleki Tükenmişlik Düzeyleri Arasındaki İlişki; Esra Toprak, Mesleki Tükenmişlik Düzeyi ile İş Tatmini Arasındaki Ilişki: Sağlık Sektöründe Bir Araştırma (Niğde: Niğde Üniversitesi, Sosyal Bilimler Enstitüsü, Yüksek Lisans Tezi, 2013).

44 Erkul, Meslek Lisesi Öğretmenlerinin Mesleki Tükenmişlik Düzeyi, 40; Kaya - Nazıroğlu, "Din Görevlilerinin Mesleki Tutum ve Motivasyon Düzeylerini Etkileyen Bazı Faktörler”, 45-51; Küçük, Din Görevlilerinin Mesleki Yeterlilikleri ile Mesleki Tutum ve Motivasyonları Arasındaki İlişkinin İncelenmesi, 81-93; Ardıç - Polatc1, "Tükenmişlik Sendromu Akademisyenler Üzerinde Bir Uygulama", 85; Hüseyin İbrahim Yeğin, “Din Kültürü ve Ahlak Bilgisi Öğretmenlerinin Tükenmişlik Düzeyleri”, Ekev Akademi Dergisi 18/58 (2014), 329. 
yaşamaları durumunda kurumsal olarak destek verilmesi bu kişilerin mesleki motivasyonlarının artmasına yardımcı olabilir.

2. Genellikle işini çok seven çalışanlar hem iş konusunda hem de akademik olarak kendilerini geliştirmekte bununla birlikte işle ilgili beklentileri de artmaktadır. Din alanında personel istihdam eden kurumların bu durumu dikkate alarak maddi ve manevi ödül kazanma imkânları sunması çalışanlarının memnuniyetini artırma açısından gereklidir.

3. Diğer alanlarda olduğu gibi din alanında da meslek seçerken bireylerin yetenekleri ve istekleri göz önüne alınarak doğru bir yönlendirme yapılmalıdır. Ayrıca bireylere sevmediği mesleği yapmak zorunda bırakacak baskı ve yönlendirmeler yapilmamalidir.

4. Kişinin mesleği benimsemesinde en etkili faktörlerin başında iş güvencesi geldiği bilinciyle araştırma görevlilerinin sözleşmeli istihdamı yerine kadrolu çalıștırılmaları; doktoraları bittiğinde de varsa Dr. öğretim üyesi kadrosuna atanmaları, buna imkân olmadığında da eğitimlerine uygun bir mesleğe atanmaları sağlanmalıdır.

5. Bu çalışmada Millî Eğitim Bakanlığında, Diyanet İşleri Başkanlığında ve dinî yükseköğretim kurumlarında çeşitli unvanlarda çalışanların çeşitli değişkenlere göre mesleki tutum ve tükenmişlik düzeyleri incelenmiştir. Bu çalışanların mesleki tükenmişliklerinin nedenlerini tespit etmeye ve çözüm üretmeye dönük çalışmaların yapılmasına ihtiyaç vardır.

\section{Kaynakça}

Abanoz, Süleyman. Din Eğitimci ve Öğreticilerinin Mesleki Tutumları ile Tükenmişlik Düzeyleri Arasındaki İlişki. Eskişehir: Eskişehir Osmangazi Üniversitesi, Sosyal Bilimler Enstitüsü, Doktora Tezi, 2019.

Acar Arasan, Başak Nur. Akademisyenlerde Yaşam Doyumu İş Doyumu ve Mesleki Tükenmişlik Düzeylerinin Belirlenmesine Yönelik Bir Araştırma. Uşak: Uşak Üniversitesi, Sosyal Bilimler Enstitüsü, Yüksek Lisans Tezi, 2010.

Akpınar, Ali. "Diyanet”. Erişim 11 Haziran 2021. Cami Merkezli Din Hizmeti Verenlerde Görülen Bazı Eksiklikler ve Bunların Giderilmesine Yönelik Teklifler (aliakpinar.net)

Alizada, Sona Khaim. Akademik Personelin Tükenmişlik Açısından Değerlendirilmesi ve İş Doyumuna Yönelik Bir Araştırma. İstanbul: İstanbul Aydın Üniversitesi, Sosyal Bilimler Enstitüsü, Yüksek Lisans Tezi, 2017.

Allport, Gordon W. “Attitudes”. A Handbook of Social Psychology. ed. Carl Murchison. Worcester: Clark University Press, 1935.

Ardıç, Kadir - Polatcı, Sema. "Tükenmişlik Sendromu Akademisyenler Üzerinde Bir Uygulama (GOÜ Örneği)". Gazi Üniversitesi İktisadi ve İdari Bilimler Fakültesi Dergisi 10/2 (Aralık 2008), 69-96. Arkonaç, Sibel Ayşen. Sosyal Psikoloji. İstanbul: Alfa Basın Yayın Dağıtım, 2. Basım, 2001.

Bayrakdar, Nazım. Din Kültürü ve Ahlak Bilgisi Öğretmenlerinin Mesleki Tükenmişlik Algıları. Kayseri: Erciyes Üniversitesi, Sosyal Bilimler Enstitüsü, Doktora Tezi, 2014.

Berber, Sena. Tükenmişlik ve İş Tatmini Arasındaki İlişki: Kule Personeli Üzerine Bir Araştırma. Ankara: Gazi Üniversitesi, Sosyal Bilimler Enstitüsü, Yüksek Lisans Tezi, 2011. 
Boyar, Ener. Türkiye'de Muhasebe Meslek Mensuplarının Mesleki Tükenmişlik Durumlarının Araştırılması. Sakarya: Sakarya Üniversitesi, Sosyal Bilimler Enstitüsü, Doktora Tezi, 2011.

Cüceloğlu, Doğan. İnsan ve Davranışı. İstanbul: Remzi Kitabevi, 13. Basım, 2004.

Çağlıyan, Yasemin. Tükenmişlik Sendromu ve İş Doyumuna Etkisi (Devlet ve Vakıf Üniversitelerindeki Akademisyenlere Yönelik Alan Araştırması). Kocaeli: Kocaeli Üniversitesi Sosyal Bilimler Enstitüsü, Yüksek Lisans Tezi, 2007.

Çakır, Özlem vd., "Mersin Üniversitesi Eğitim Fakültesi 1999-2000 Yılı Öğretmenlik Meslek Bilgisi Programının (ÖMBP) Çeşitli Değişkenler Açısından Değerlendirilmesi”. Mersin Üniversitesi Araștırma Fonu Saymanliğı (ÖÇ) 2000-1 Nolu Araştırma Projesi, 2000.

Çanakçı, Ahmet Ali. "Cami Cemaatinin Din Görevlilerine Bakışı: Balıkesir Örneği”. Balıkesir Üniversitesi İlahiyat Fakültesi Dergisi 1/2 (Aralık 2015), 253-282.

Çetin Akbulut, Nihal. Tükenmişlik Sendromu ve İş Tatmini Arasındaki İlişki. İstanbul: Marmara Üniversitesi, Sosyal Bilimler Enstitüsü, Yüksek Lisans Tezi, 2010.

Çetin, Şaban. "Öğretmenlik Mesleği Tutum Ölçeğinin Geliştirilmesi (Geçerlik ve Güvenirlik Çalışması)”. Gazi Üniversitesi Endüstriyel Sanatlar Eğitim Fakültesi Dergisi 18 (2006), 28-37.

DỉB, Diyanet İşleri Başkanlığı. "2020 Yılı 4-B Sözleşmeli (KKÖ, İ-H, M-K) Alımı Sınavı (Revize)”. Erişim 11 Haziran 2021. 2020 Yılı 4-B Sözlesmeli (KKÖ, İ-H, M-K) Alımı Sınavı (Revize) (diyanet.gov.tr)

Doğan, Ahmet. Din Görevlilerinin Mesleki Aidiyetleri, Mesleki Tükenmişlik Tutumları ve Hizmet İçi Eğitime Bakışları. Ankara: Ankara Üniversitesi, Sosyal Bilimler Enstitüsü, Doktora Tezi, 2013.

Erkul, Atilla. Meslek Lisesi Öğretmenlerinin Mesleki Tükenmişlik Düzeyi. İstanbul: Bahçeşehir Üniversitesi, Eğitim Bilimleri Enstitüsü, Yüksek Lisans Tezi, 2014.

Erkuş, Adnan. Psikoloji Terimleri Sözlüğü. İstanbul: Doruk Yayınları, 1994.

Günay, Ahmet. Kabin Ekiplerinde İş Doyumu ve Tükenmişlik Sendromu. Eskişehir: Anadolu Üniversitesi, Sosyal Bilimler Enstitüsü, Yüksek Lisans Tezi, 2016.

Freudenberger, Herbert J. “Staff burn-out”. Journal of Social Issues 30 (1974), 159-165. https://doi.org/10.1111/j.1540-4560.1974.tb00706.x

İl, Zeliha. Muhasebe Meslek Mensuplarının Mesleki Tükenmişlik Durumlarının Araştırlması: Erzurum ve Erzincan Uygulaması. Erzincan: Erzincan Binali Yıldırım Üniversitesi, Sosyal Bilimler Enstitüsü, Yüksek Lisans Tezi, 2018.

İşilanlarım. “ỉlahiyat Mezunları Ne İş Yapar? İlahiyat İş Olanakları Nelerdir?”. Erişim 11 Haziran 2021. İlahiyat Mezunları Ne İş Yapar? İlahiyat İş Olanakları Neler? | İş ̇̇lanlarım.Net Güncel İş İlanları (isilanlarim.net)

Kağıtçıbaşı, Çiğdem. İnsan ve İnsanlar. İstanbul: Evrim Yayınları, 8. Basım, 1988.

Karasar, Niyazi. Bilimsel Araștırma Yöntemi. Ankara: Nobel Yayın Dağıtım, 10. Basım, 1999.

Kaya, Mevlüt - Nazıroğlu, Bayramali. "Din Görevlilerinin Mesleki Tutum ve Motivasyon Düzeylerini Etkileyen Bazı Faktörler”. Ondokuz Mayıs Üniversitesi İlahiyat Fakültesi Dergisi 26-27 (2008), 25-53.

Kaya, Mevlüt. Din Eğitiminde İletişim ve Dini Tutum. İstanbul: Etüt Yayınları, 1998.

Kılınç, Bülent. Fen Bilgisi Öğretmenlerinin Mesleki Tükenmişlik Düzeylerinin Bazı Değişkenler Açısından İncelenmesi. Elâzığ: Fırat Üniversitesi, Eğitim Bilimleri Enstitüsü, Yüksek Lisans Tezi, 2018.

Kocaman, Merve. Şiddete Uğrayan Kadınlarda Dinî Başa Çıkma (Erzincan Örneği). Bursa: Uludağ Üniversitesi, Sosyal Bilimler Enstitüsü, Yüksek Lisans Tezi, 2019.

Korkmaz, Gülbahar. İlköğretim Okullarında Görev Yapan Öğretmenlerin Okul Yaşam Kalitesini Algılama Düzeyleri ve Mesleki Tutumlarının İncelenmesi. Adana: Çukurova Üniversitesi Sosyal Bilimler Enstitüsü, Yüksek Lisans Tezi, 2009. 
Koyuncu Şahin, Mine. Okul Öncesi Öğretmenlerinin Öz Güvenleri ve Mesleki Tutumlarının İncelenmesi. Afyon: Afyon Kocatepe Üniversitesi, Sosyal Bilimler Enstitüsü, Yüksek Lisans Tezi, 2015.

Kula, Mustafa Naci. “Bedensel Engellilere Yönelik Tutumlar ile Dini Tutumlar Arasındaki İlişki Üzerine Bir Araştırma”. İslami Araştırmalar Din Psikolojisi Özel Sayısı 19/3 (2006), 511-525.

Küçük, Nurettin. Din Görevlilerinin Mesleki Yeterlilikleri ile Mesleki Tutum ve Motivasyonları Arasındaki İlişkinin İncelenmesi (Karabük İli Örneği). Samsun: Ondokuz Mayıs Üniversitesi Sosyal Bilimler Enstitüsü, Yüksek Lisans Tezi, 2015.

Maslach, Christina - Jackson, Susane E. “The Measurement of Experienced Burnout”. Journal of Occupational Behaviour 2 (1981), 99-113.

Öztürk, Mehmet Ali. Sınıf Öğretmenlerinin İş Yükü Algısı ile Mesleki Tükenmişlik Düzeyleri Arasındaki İlişki. Kırşehir: Kırşehir Ahi Evran Üniversitesi, Sosyal Bilimler Enstitüsü, Yüksek Lisans Tezi, 2019.

Peker, Hüseyin. Din Psikolojisi. Samsun: Sönmez Matbaa ve Yayınevi, 1993.

Tezbaşaran, Ata. Likert Tipi Ölçek Geliştirme Kılavuzu. Ankara: Türk Psikologlar Derneği Yayınları, 1997.

Thurstone, Louis Leon. "Attitudes can be Measured”. American Journal of Sociology 33 (1928), 529-554. https://doi.org/10.1086/214483

Toprak, Esra. Mesleki Tükenmişlik Düzeyi ile İş Tatmini Arasindaki İlişki: Sağlı Sektöründe Bir Araştırma. Niğde: Niğde Üniversitesi, Sosyal Bilimler Enstitüsü, Yüksek Lisans Tezi, 2013.

Tuğrul, Belma - Çelik, Eylem. "Normal Çocuklarla Çalışan Anaokulu Öğretmenlerinde Tükenmişlik”. Pamukkale Üniversitesi Eğitim Fakültesi Dergisi 2/12 (2002), 1-11.

Üstüner, Mehmet. "Öğretmenlik Mesleğine Yönelik Tutum Ölçeğinin Geçerlik ve Güvenirlik Çalışması”. İnönü Üniversitesi, Kuram ve Uygulamada Eğitim Yönetimi 45/45 (2006), 109-127.

Yeğin, Hüseyin İbrahim. "Din Kültürü ve Ahlak Bilgisi Öğretmenlerinin Tükenmişlik Düzeyleri". Ekev Akademi Dergisi 18/58 (2014), 315-332.

Yorulmaz, Yılmaz Ilker - Altınkurt, Yahya. "The Examination of Teacher Burnout in Turkey: a Meta-Analysis". Turkish Journal of Education 7/1 (2018), 34-54.

"https://doi.org/10.19128/turje.348273. 